\title{
EL RÉGIMEN SANCIONADOR DE LA LEY DE SEGURIDAD CIUDADANA Y SU ADECUACIÓN A LA CONSTITUCIÓN: A PROPÓSITO DE LAS SSTC 172/2020, DE 19 DE NOVIEMBRE, Y 13/2021, DE 28 DE ENERO'
}

\author{
CARMEN MARTÍN FERNÁNDEZ² \\ Universidad de Córdoba
}

\begin{abstract}
Cómo citar/Citation
Martín Fernández, C. (2021).

El régimen sancionador de la Ley de Seguridad Ciudadana y su adecuacion a la Constitucion: a propósito de las SSTC 172/2020, de 19 de noviembre, y 13/2021, de 28 de enero. Revista de Administración Pública, 216, 223-258. doi: https://doi.org/10.18042/cepc/rap.216.08
\end{abstract}

\section{Resumen}

Al igual que sus predecesoras, la actual Ley de Seguridad Ciudadana ha sido duramente criticada. De ahí su apodo de «ley mordaza». Los sectores más críticos vieron en ella, incluso desde antes de su aprobación, unas restricciones injustificadas y desproporcionadas de algunos derechos fundamentales y libertades públicas, singularmente del derecho de reunión. Por eso, y por otras posibles vulneraciones de garantías constitucionales, como los principios de tipicidad y de seguridad jurídica (arts. 25.1 y $9.3 \mathrm{CE}$ ), fue objeto de dos recursos de inconstitucionalidad. En este trabajo se analizan las sentencias del Tribunal Constitucional que los han resuelto, en concreto, se estudian sus pronunciamientos sobre el régimen sancionador de la LOPSC y las razones que han llevado al máximo intérprete de nuestra Norma Suprema a declarar su constitucionalidad.

\footnotetext{
Proyecto de investigación "Seguridad pública, actividad administrativa de limitación y derecho sancionador", financiado por el Ministerio de Ciencia, Innovación y Universidades (MCIU), la Agencia Estatal de Investigación (AEI) y el Fondo Europeo de Desarrollo Regional (FEDER).

Ref. PGC2018-093760-B-I0

2 Contratada predoctoral FPU en el Área de Derecho Administrativo de la Universidad de Córdoba.
} 


\section{Palabras clave}

Seguridad ciudadana; régimen sancionador; principio de tipicidad; efecto desaliento; derecho de reunión.

\section{Abstract}

The current Citizen Security Law has been strongly criticised. Hence its nickname "gag law.» Even before its approval, the most critical sectors saw in this law an unjustified restriction to several fundamental rights, specifically of the assembly freedom. For this reason, and because presumably infringe almost systematically the principle of legality and legal certainty when classifying infractions, this law has been the subject of two appeals. In this paper, the judgments of the Constitutional Court that resolve them are analysed, specifically its pronouncements about the system of sanctions of the LOPSC and the reasons that have justified the statement of its constitutionality.

\section{Keywords}

Citizen security; system of sanctions; principle of legality; chilling effect; freedom of assembly. 


\section{SUMARIO}

I. INTRODUCCIÓN: LA LOPSC Y LAS CRÍTICAS VERTIDAS EN SU CONTRA. II. LOS RECURSOS DE INCONSTITUCIONALIDAD INTERPUESTOS FRENTE A LA LOPSC Y LAS SENTENCIAS QUE LOS RESUELVEN: LAS SSTC 172/2020 Y 13/2021. III. SOBRE EL CONCEPTO DE SEGURIDAD CIUDADANA Y SU FUNCIÓN COMO BIEN JURÍDICO PROTEGIDO. IV. SOBRE LA EXIGENCIA DE TIPICIDAD Y SU RELATIVIDAD: 1. Los pronunciamientos concretos de las SSTC 172/2020 y 13/2021. 2. La relatividad del principio de tipicidad. V. LOS PRONUNCIAMIENTOS DE LAS SENTENCIAS SOBRE LAS INFRACCIONES RELATIVAS AL DERECHO DE REUNIÓN. EL ESCASO PROTAGONISMO DE LA DOCTRINA DEL EFECTO DESALIENTO: 1. La doctrina del efecto desaliento o chilling effect. 2. Los pronunciamientos sobre las infracciones impugnadas vinculadas al derecho fundamental de reunión. VI. LA ÚNICA DECLARACIÓN DE INCONSTITUCIONALIDAD: EL INCISO «NO AUTORIZADO» DEL ART. 36.23 LOPSC. VII. SIN NOVEDADES SOBRE LA FRONTERA ENTRE EL DERECHO PENAL Y EL DERECHO ADMINISTRATIVO SANCIONADOR. VIII. CONCLUSIONES.

\section{INTRODUCCIÓN: LA LOPSC Y LAS CRÍTICAS VERTIDAS EN SU CONTRA}

El derecho administrativo sancionador encuentra su prueba de fuego en el ámbito de la seguridad ciudadana, sector de actividad administrativa delicado por la naturaleza de los bienes jurídicos que se encuentran en juego, controvertido per se, no exento de problemas ni siquiera en su estado más pacífico. Tanto, que "cuantos han tenido el atrevimiento de legislar sobre ella han salido escaldados»" No hay más que ver la reacción social y doctrinal que, en todos los tiempos y durante todos los regímenes, han despertado las leyes que lo regulan. A la actual Ley Orgánica 4/2015, de 30 de marzo, de Protección de la Seguridad Ciudadana

3 M. Rebollo Puig (2019a), «La trama de la Ley de Seguridad Ciudadana», en M. Izquierdo Carrasco y L. Alarcón Sotomayor (dirs.), Estudios sobre la Ley Orgánica de Seguridad Ciudadana (págs. 31-170), Navarra: Aranzadi, pág. 34. 
(en adelante, LOPSC), se le conoce como «ley mordaza». A su predecesora, la Ley Orgánica 1/1992, de 21 de febrero, sobre Protección de la Seguridad Ciudadana (LOPSC/92), se la bautizó como «ley de la patada en la puerta» ${ }^{4}$. Por no hablar de la Ley 45/1959, de 30 de julio, de Orden Público, tachada de represora por la época y el régimen en que se aprobó. Se hablaba de una ley franquista para oficializar el miedo. Lo mismo ocurrió con la Ley de Orden Público de 1933, acusada — incluso por la doctrina administrativista - de entregar a los ciudadanos a la arbitrariedad de la autoridad gubernativa ${ }^{5}$. Pocas normas aprobadas por las Cortes españolas han tenido tanto eco como estas leyes ${ }^{6}$.

Queda patente que no se trata de un asunto ideológico, pues todas las leyes, independientemente del régimen en que hayan sido aprobadas y del color político del gobierno que las haya impulsado, han sido igualmente denostadas. La cuestión es otra. Acierta Casino Rubio cuando afirma que «las críticas que han ido saliendo prueban el interés de la materia» ${ }^{7}$. La seguridad ciudadana «responde a una de las necesidades humanas permanentes más fuertemente sentidas por amplios sectores sociales y hunde sus raíces en una de sus aspiraciones más profundas: la seguridad personal ${ }^{8}$. Es de extraordinaria relevancia la plaza que ocupa el interés general que se encuentra en juego, sin cuya garantía los demás intereses generales devienen irrealizables. El orden público, con independencia de su con-

4 Tres años después de su entrada en vigor, Berriatúa señaló que «la judicatura, la doctrina y los defensores de la democracia y del Estado de derecho vieron en ella [en la seguridad ciudadana] y en su regulación en la Ley Orgánica 1/1992, de 21 de febrero, sobre Protección de la Seguridad Ciudadana un atentado contra la libertad en nombre de la eficacia policial [...], una vulneración de los derechos fundamentales regulados en la Constitución de 1978 y un retorno de la democracia hacia formas represivas, propias de un sistema autoritario que felizmente se creía superado». Y no dudó en afirmar que la discusión parlamentaria de dicha ley «supuso políticamente uno de los momentos más fuertes de acoso al gobierno socialista y a su Presidente Felipe González». Véase J. Berriatúa San Sebastián (1995), "Aproximación al concepto de seguridad ciudadana», Revista Vasca de Administración Pública, 41, págs. 737-760 (pág. 737).

5 Así lo expresó, entre otros, Royo Villanova. Apud M. Ballbé Mallol (1985), Orden público y militarismo en la España constitucional (1812-1983), 2a ed., Madrid: Alianza Editorial (pág. 359). Más adelante, el autor seńala que los acontecimientos posteriores demostraron cuán acertadas eran las críticas y que la Ley de Orden Público de 1933 «completaba las bases de un Estado autoritario» (pág. 360).

6 En este sentido, véase J. Barcelona Llop (1993), «Las infracciones y sanciones administrativas en la Ley Orgánica 1/1992, sobre Protección de la Seguridad Ciudadana. Algunos aspectos problemáticos», en J. Fernández Entralgo, G. Portilla Contreras y J. Barcelona Llop, Seguridad ciudadana: materiales de reflexión critica sobre la ley Corcuera (págs. $117-$ 177), Madrid: Trotta (pág. 117).

7 M. Casino Rubio (2015), Seguridad pública y Constitución, Madrid: Tecnos (pág. 27).

8 J. Berriatúa San Sebastián (1995: 737-738). 
creta y compleja definición ${ }^{9}$, «no es un interés general más, sino el indispensable y vital, el que ante todo debe asegurar el Estado a través de la Administración: sin orden público los demás intereses generales son de imposible realización efectiva y los ciudadanos no disfrutarán realmente ni siquiera de sus derechos fundamentales, que se convierten en una falacia» ${ }^{10}$. El orden público y la seguridad ciudadana constituyen una materia delicada en sí misma, pues en ella se ponen en tensión dos de los valores más importantes de todo Estado democrático de derecho: la libertad y la seguridad, con el peligro de que "la primera sin la segunda se convierte en caos y la segunda sin la primera en tiranía ${ }^{11}$, pudiendo, por tanto, decirse que "la indispensable seguridad es condición de la libertad y que ésta determina aquella $»^{12}$. Por eso, López-Nieto señala como meta de la acción política «conseguir el máximo orden dentro del máximo de libertad», ya que, añade el autor, «no es lícito olvidar que a más orden existe menos libertad, y a más libertad, menos orden ${ }^{13}$. Resulta, por tanto, fundamental, como ya advirtió Casino, «calibrar muy bien la permanente tensión entre libertad y seguridad, a fin de impedir que el mantenimiento del orden lato sensu se convierta finalmente en el ácido en el que terminan por disolverse los derechos y libertades públicas» ${ }^{14}$. Es aquí donde reside el quid de la cuestión.

En resumen, el devenir de la historia ha ido poniendo de manifiesto cómo, independientemente de su contenido y de la ideología de sus creadores, todas

9 M. Hauriou (1914), Prècis de Droit Administratif et de Droit Public, 8ª ed., París: Sirey (pág. 517), lo definió como un orden material y exterior, un estado de hecho contrario al desorden. Y la doctrina mayoritaria considera que se trata de un concepto jurídico indeterminado, pero dentro del cual pueden comprenderse los siguientes elementos: la seguridad, la salubridad, la tranquilidad y la moralidad públicas. A este respecto, véase $M$. Rebollo Puig (2019b), «La actividad administrativa de limitación», en M. López Benítez y M. Izquierdo Carrasco (coords.), Derecho Administrativo, Tomo III: Modos y medios de la actividad administrativa (págs. 19-46), 2a ed., Madrid: Tecnos (págs. 28-29).

10 M. Rebollo Puig (2019b: 31). Dada su importancia, como afirma el autor en el prólogo a la obra de Casino Rubio, Seguridad Pública y Constitución, «no es de extrañar que hasta el liberalismo más radical, que quería someter a la Administración a estrictos límites, le diera los más extensos poderes para preservar el orden público». Explicando después que «en el fondo, no han cambiado tanto las cosas y, aun los Estados con tantas pretensiones y fines como los actuales, siguen respondiendo a la misma idea y siguen teniendo como fin primero y principal el mantenimiento de la seguridad. También su Administración la tiene como fin esencial, se la llame orden público o seguridad, y se apellide a ésta de pública o de ciudadana o como se quiera». Véase Casino Rubio (2015: 13-14).

11 Rebollo Puig (2019a: 167).

12 L. Parejo Alfonso (2003), «Reflexiones sobre la libertad, la seguridad y el Derecho», Justicia Administrativa, 21, págs. 5-19 (pág. 5).

13 F. López-Nieto y Mallo (1992), Seguridad ciudadana y orden público, Madrid: El Consultor de los Ayuntamientos y de los Juzgados (pág. 16).

14 Casino Rubio (2015: 27). 
las leyes reguladoras del orden público han sido desautorizadas. En concreto, la LOPSC ha sido objeto de críticas acerbas, que la han acusado «no ya de ser más o menos defectuosa o de tener algún precepto inconstitucional, sino de poner en peligro las libertades públicas y el mismo Estado democrático de Derecho» ${ }^{15}$. Seguramente esos mordaces improperios hayan perdido toda su esencia con el mero transcurso del tiempo y el devenir de los hechos, que no han evidenciado catástrofe democrática alguna ni ninguna quiebra de nuestros valores constitucionales. Pero son las SSTC 172/2020, de 19 de noviembre y 13/2021, de 28 de enero, que analizo en este trabajo, las que han zanjado la cuestión.

\section{LOS RECURSOS DE INCONSTITUCIONALIDAD INTERPUESTOS FRENTE A LA LOPSC Y LAS SENTENCIAS QUE LOS RESUELVEN: LAS SSTC $172 / 2020$ Y $13 / 2021$}

El 21 de mayo de 2015 tuvo entrada en el registro general del TC el recurso de inconstitucionalidad 2896-2015, promovido por noventa y siete diputados del Grupo Parlamentario Socialista, once del Grupo Parlamentario La Izquierda Plural, cuatro del Grupo Parlamentario Unión Progreso y Democracia y dos del Grupo Parlamentario Mixto del Congreso de los Diputados, contra los arts. 19.2, 20.2, 36.2, 36.23, 37.1 en relación con los arts. 30.3, 37.3 y 37.7, así como la disposición final primera de la LOPSC. Unos días más tarde, el 30 de junio de 2015, tuvo entrada en dicho registro el segundo recurso de inconstitucionalidad interpuesto frente a la LOPSC, el 3848-2015, promovido por el Parlamento de Cataluña contra los arts. 20, 35.1, 36.1, 36.2, 36.8, 36.22, 36.23, 37.7 y la disposición final primera de la LOPSC. Por providencias de 9 de junio y de 21 de julio de 2015, respectivamente, el Pleno del TC acordó admitir a trámite los mencionados recursos.

El 19 de noviembre de 2020 el Tribunal Constitucional dictó la sentencia 172/2020 que ha resuelto el primero de los recursos interpuestos frente a la LOPSC. Fue publicada en el BOE el 22 de diciembre de ese mismo año. En dicha resolución, el Pleno del TC ha avalado la constitucionalidad de la LOPSC, salvo el requisito de la necesidad de autorización para el uso de «imágenes o datos de autoridades o miembros de las Fuerzas y Cuerpos de Seguridad del Estado» que estaba previsto en su art. 36.23. De esta forma, el máximo intérprete de la Constitución ha desestimado la mayoría de las impugnaciones planteadas por los recurrentes del Congreso de los Diputados. El 28 de enero de 2021 el Tribunal Constitucional dictó la Sentencia 13/2021 que resolvió el segundo recurso de inconstitucionalidad formulado contra la LOPSC. Esta resolución fue publicada en el BOE el 23 de

15 Rebollo Puig (2019a: 33-34). 
febrero. En ella, el Pleno del TC vuelve a avalar la constitucionalidad de la LOPSC, desestimando todas las alegaciones de los parlamentarios catalanes.

Estas sentencias han aportado elementos de interés, incluso de interés general más allá del propio sector de la seguridad ciudadana. Como quiera que el único precepto anulado es sancionador, a esta tipología limitaré mi comentario. Quedarán fuera otros como los concernientes a los registros corporales o al rechazo en las fronteras de Ceuta y Melilla, merecedores de un comentario específico. Dentro del enjuiciamiento de los preceptos sancionadores de la LOPSC hay, en realidad, dos géneros de posibles inconstitucionalidades. De un lado, aquellas que resultan de la vulneración de las garantías que la Constitución erige frente a toda expresión de la potestad sancionadora de la Administración que, dejando al margen las garantías formales (construidas sobre la base del art. $24 \mathrm{CE}$ ), se producirían por la infracción de todas las que el TC ha considerado ínsitas en el art. 25 CE. De otro lado, aquellas que se producirían porque el precepto sancionador, al margen de prever un castigo, contiene implícitamente una norma material restrictiva de la libertad afectada. En este último caso, lo que estaría en juego no es el respeto al art. 25, sino a los arts. 20 o $21 \mathrm{CE}$ según concierna a la libertad de información y expresión o a la de reunión y manifestación. Si, por ejemplo, lo cuestionado es un precepto legal que sanciona determinadas manifestaciones en las proximidades del Congreso de los Diputados, su inconstitucionalidad puede no tener nada que ver con la potestad sancionadora ni con los arts. 24 y $25 \mathrm{CE}$, sino con el simple hecho de que ese precepto legal supone un límite inconstitucional al derecho de manifestación, inconstitucionalidad que se daría por igual aunque la norma no hubiera previsto sanciones, sino cualquier otra consecuencia para la ilicitud que declara. Esos dos planos se conectan con especial intensidad por la doctrina de los efectos desalentadores en cuya virtud pudiera ser inconstitucional una norma que castiga una conducta no amparada por un derecho fundamental cuando, por miedo a sufrir esas consecuencias, podría llevar a no ejercer lícitamente el derecho fundamental en cuestión. Surge así una especie de límite adicional a las normas sancionadoras, no para todas, sino solo para las que reprimen conductas limítrofes a las de ejercicio de derechos fundamentales. Todo esto, en mayor o menor medida, aparece en estas sentencias del Tribunal Constitucional sobre la LOPSC y será objeto de este comentario.

\section{SOBRE EL CONCEPTO DE SEGURIDAD CIUDADANA Y SU FUNCIÓN COMO BIEN JURÍDICO PROTEGIDO}

La STC 172/2020, en su FJ 3, como frontispicio de toda su argumentación, se embarca en la difícil tarea de ofrecer una noción de seguridad ciudadana ${ }^{16}$.

16 En esto se diferencia de la STC 341/1993, de 18 de noviembre, que resolvió el recurso contra la LOPSC/92 y que no hizo ningún pronunciamiento acerca del significado de la 
En la Constitución se habla de seguridad ciudadana (art. 104.1), de seguridad pública (art. 149.1.29a) y de orden público (arts. 16.1 y 21.2). Y, a partir de ahí, se han hecho esfuerzos por distinguir esos tres conceptos. La mencionada sentencia entra de lleno en este debate y suministra criterios sólidos para resolverlo. Pero, tan importante como ello, es la función que atribuye a la noción de seguridad ciudadana para interpretar las infracciones establecidas en la LOPSC.

La doctrina constitucional viene considerando desde antiguo (STC 33/1982, de 8 de junio) la seguridad pública como un concepto más preciso o estricto que el de la noción tradicional de «orden público» (que incluye otros aspectos, como la salubridad pública), y la define como la actividad dirigida a la protección de personas y bienes (seguridad en sentido estricto) y al mantenimiento de la tranquilidad u orden ciudadano.

Por otra parte, define la seguridad ciudadana como «el estado en el que el conjunto de la ciudadanía goza de una situación de tranquilidad y estabilidad en la convivencia que le permite el libre y pacífico ejercicio de los derechos y libertades que la Constitución y la Ley les reconocen». La considera una parte integrante de la más amplia noción de seguridad pública; una parte de gran importancia y dotada de perfiles propios, pero que, sin embargo, no abarca todos los aspectos que definen su ámbito material. Según el TC, la seguridad ciudadana es la actividad encaminada a «asegurar un ámbito de convivencia en el que sea posible el ejercicio de los derechos y libertades, mediante la eliminación de la violencia y la remoción de los obstáculos que se opongan a la plenitud de aquellos». Precisamente por eso, es un concepto más estrecho que el de seguridad pública, que abarca también la protección civil ${ }^{17}$.

seguridad ciudadana, lo que fue criticado por algún sector doctrinal. Véase T. Freixes Sanjuán y J. C. Remotti Carbonell (1995), «La configuración constitucional de la seguridad ciudadana», Revista de Estudios Políticos, 87, págs. 141-162 (pág. 158). Según los autores, «el Tribunal Constitucional hubiera debido entrar a definir a la seguridad ciudadana a fin de obtener el referente material sobre el cual valorar la constitucionalidad del desarrollo legislativo y no realizar el juicio de constitucionalidad únicamente sobre si las reglas concretas de la ley recurrida vulneraban o no los derechos constitucionales».

17 L. de la Morena y de la Morena (1986), «La seguridad pública como concepto jurídico indeterminado: su concreta aplicación a los traspasos de servicios en materia de espectáculos públicos», Revista de Administración Pública, 109, págs. 321-362 (pág. 332). El autor define la protección civil como «una modalidad de la seguridad pública en la que el riesgo o peligro que la define, al no provenir específicamente de comportamientos humanos susceptibles de un previo control, sino, por lo común, de hechos naturales imprevisibles e inevitables (vis major), antes se organiza con vistas a asegurar una eficaz actuación reparadora en favor de los damnificados, una vez ocurrido el siniestro, que a prevenir éste por anticipado». También Berriatúa San Sebastián (1995: 757) explica que la protección civil forma parte de la noción más amplia de seguridad pública, pero diferenciándose de la seguridad ciudadana por razón de las causas generadoras del riesgo, «que en la seguridad ciudadana provienen de actos humanos constitutivos generalmente de delito o falta penales, y en la 
De esta forma, el máximo intérprete de la Constitución contradice al legislador, que en el preámbulo de la LOPSC concibe a la seguridad pública y a la seguridad ciudadana como sinónimos, entendiendo por tales la actividad dirigida a la protección de personas y bienes y al mantenimiento de la tranquilidad ciudadana ${ }^{18}$.

Tendríamos, por tanto, conforme a esta interpretación constitucional, un concepto amplio de orden público del que forma parte la seguridad pública, siendo la seguridad ciudadana un componente de esta última. Se aleja así el TC de aquellas opiniones doctrinales que conciben el orden público como una parte de la seguridad pública ${ }^{19}$. También de aquellas otras que consideran ambos conceptos equivalentes ${ }^{20}$. E igualmente se aparta de las tesis que los aprecian como sinónimos ${ }^{21}$.

protección civil de causas naturales de calamidad pública o catástrofe extraordinaria» (pág. 754). En el mismo sentido, véase López-Nieto y Mallo (1992: 32).

18 Aunque lo cierto es que después el legislador también excluye expresamente del ámbito de aplicación de la LOPSC aspectos que, por el contrario, forman parte de la seguridad pública (la seguridad aérea, marítima, ferroviaria, vial o en los transportes), por lo que parece admitir cierta diferencia entre ambos conceptos.

19 En esta línea, véase M. J. Izu Belloso (1988), «Los conceptos de orden público y seguridad ciudadana tras la Constitución de 1978", Revista Española de Derecho Administrativo, 58, págs. 233-254 (págs. 246 y 250-251); J. L. Carro Fernández-Valmayor (1990), «Sobre los conceptos de orden público, seguridad ciudadana y seguridad pública», Revista Vasca de Administración Pública, 27, págs. 9-26 (pág. 22) y J. L. Blasco Díaz (2016), «Seguridad ciudadana y potestad sancionadora», en M. L. Cuerda Arnau y J. A. García Amado (dirs.), Protección jurídica del orden público, la paz pública y la seguridad ciudadana (págs. 15-35), Valencia: Tirant lo Blanch (pág. 15).

20 Es el caso de L. de la Morena y de la Morena (1986: 321), que utiliza ambas expresiones como intercambiables. Una postura parecida se encuentra en I. Agirreazkuenaga (1994), "Contexto de la Ley de Seguridad Ciudadana. Análisis jurídico de los controles de identidad: voluntas legis e interpretación jurisprudencial del T.C.", Revista Vasca de Administración Pública, 38, págs. 13-56 (págs. 19-20).

21 Un exponente de esta teoría es, de nuevo, Izu Belloso (1988: 244 y 252). Por su parte, Blasco Díaz (2016: 15) admite que a la seguridad pública suele hacerse referencia en ocasiones como seguridad ciudadana, pero reconoce, siguiendo a Aguado i Cudolà, que puede entenderse que esta es un ámbito de aquella, ya que, a juicio de este otro autor, la seguridad pública engloba la seguridad ciudadana y la protección civil. Véase V. Aguado i Cudolà (2015), «Los conceptos de seguridad pública y seguridad ciudadana. Título competencial. Fines y organización administrativa», en A. Palomar Olmeda (coord.), El nuevo régimen de la seguridad ciudadana (págs. 19-80), Navarra: Aranzadi (pág. 28). Podría decirse que Izquierdo Carrasco forma parte de este sector doctrinal que identifica seguridad pública con seguridad ciudadana. Pero realmente no es así. Lo que ocurre es que, en su estudio sobre el régimen jurídico-administrativo de la seguridad privada, Izquierdo renuncia al intento de establecer una distinción entre ambos conceptos por no ser determinante en su exposición. A este respecto, véase M. Izquierdo Carrasco (2004), La seguridad privada: régimen jurídico-administrativo, Valladolid: Lex Nova (págs. 42-43). 
La noción que acoge el TC está más en concordancia con lo preconizado por otro sector doctrinal que ya había acogido un concepto restrictivo de seguridad ciudadana ${ }^{22}$.

En síntesis, de abajo arriba, y de forma muy aproximada, podrían ofrecerse las siguientes definiciones:

- Seguridad ciudadana: actividad llevada a cabo por las Fuerzas y Cuerpos de Seguridad para proteger a las personas y bienes de los comportamientos humanos. Es la seguridad en sentido estricto, la ausencia del sentimiento de miedo en las personas, la tranquilidad ciudadana que nos permite ejercer nuestros derechos y libertades.

- Seguridad pública: concepto que engloba al anterior y que va más allá, pues abarca también la protección de los peligros naturales imprevisibles e inevitables; es decir, la protección civil. Por lo tanto, no equivale solo a tranquilidad y ausencia de miedo, sino también a respuesta y protección públicas ante las calamidades o catástrofes.

- Orden público: es un concepto que, aunque difícil de encasillar, se identifica con un estado material y exterior opuesto al desorden y que se refiere a condiciones imprescindibles para la vida colectiva más allá de la seguridad pública, pues abarca también, según es generalmente admitido, las condiciones mínimas de salubridad.

En suma, en lo que más directamente importa para los recursos resueltos por estas SSTC, la seguridad ciudadana forma parte del concepto de orden público y,

22 Forma parte destacada de este sector Rebollo Puig (2019a: 51, 52, 77 y 83), que concibe el orden público como el concepto más amplio, que abarca dentro de sí la seguridad pública, la cual, a su vez, comprende la noción de seguridad ciudadana. Para este autor, la seguridad pública es «el estado de hecho en el que no hay, o los hay en medida reducida y tolerable, peligros para la vida y la integridad física de las personas o de sus bienes provenientes de la violencia, de la negligencia, de los accidentes o catástrofes, tengan éstas origen natural o humano", siendo la seguridad ciudadana una parte de esta, en concreto, aquella parte de la seguridad pública que se ocupa solo de ciertos ataques, los ataques derivados de comportamientos humanos. Según Rebollo, la seguridad pública, junto con la salubridad y la tranquilidad públicas (e incluso con la moralidad pública), conforman la más amplia noción de orden público, entendida como el estado de hecho en el que se dan «las condiciones mínimas imprescindibles para la convivencia colectiva y para que los individuos puedan desarrollarse sin lesiones para su integridad física y sin daño para sus cosas, sin riesgos excesivos y sin miedo ni intranquilidad». También pueden considerarse partidarios de esta postura G. Fernández Farreres (1985), «Sobre la distribución de competencias en materia de seguridad pública entre el Estado y las Comunidades Autónomas a la luz de la jurisprudencia de conflictos del Tribunal Constitucional», Revista Española de Derecho Constitucional, 14, págs. 203-231 (pág. 206); y J. Barcelona Llop (1997), Policía y Constitución, Madrid: Tecnos (págs. 237-238). 
en concreto, de la seguridad pública, siendo «el estado en el que el conjunto de la ciudadanía goza de una situación de tranquilidad y estabilidad en la convivencia que le permite el libre y pacífico ejercicio de los derechos y libertades que la Constitución y la Ley les reconocen».

Lo que interesa destacar aquí es que, con independencia de que estas nociones sean útiles a otros efectos (sobre todo, para delimitar los bienes que pueden justificar las restricciones a derechos fundamentales o para fijar la distribución de competencias entre el Estado y las comunidades autónomas), para las SSTC que ahora se comentan, la definición de la seguridad ciudadana resulta útil para delimitar las infracciones: más allá de las descripciones de los tipos en las normas de la LOPSC, que muchas veces resultan poco atinadas e incompletas, la precisión sobre qué sea la seguridad ciudadana, le vale para señalar el bien jurídico protegido y la antijuridicidad de las infracciones y, con esa premisa, justificar la interpretación de los tipos. Se apunta con carácter general en el FJ $3^{\circ}$ :

«Los fines, en la medida en que precisan o configuran el bien jurídico protegido - esto es, el aspecto de la seguridad ciudadana cuya tutela jurídica se pretende- nos permiten afirmar que existe un bien jurídico protegido principal seguridad ciudadana - justo con unos bienes jurídicos secundarios o específicos que varían en cada una de las infracciones administrativas tipificadas. Las acciones u omisiones que vulneren estos bienes jurídicos singulares estarán atentando contra la seguridad ciudadana; $y$, siempre que concurran los restantes elementos del tipo, serán sancionables».

Así, puede decirse que en estas sentencias el TC determina el bien jurídico protegido por las infracciones de la LOPSC y que, con ello, asume el significado y el valor de la antijuridicidad material para interpretar los tipos. Esta forma de razonar y proceder - que implícitamente supone el rechazo de las tesis que configuran las infracciones administrativas como mera desobediencia - tiene interés no solo para el análisis de la LOPSC, sino para la configuración general del derecho administrativo sancionador en el que la idea de bien jurídico protegido por los tipos y de antijuridicidad de las infracciones encuentra aquí refuerzo.

\section{SOBRE LA EXIGENCIA DE TIPICIDAD Y SU RELATIVIDAD}

Los recurrentes (sobre todo, los parlamentarios catalanes) partían de una exigencia muy estricta de la garantía de tipicidad de las infracciones y las sanciones. Sin embargo, las sentencias comentadas evidencian que, en realidad, se trata de una exigencia relativa. No es que en estas sentencias el TC proclame expresamente y de forma genérica esta relatividad, sino que en ellas puede apreciarse una aplicación muy flexible de la exigencia de tipicidad al enjuiciar cada uno de los preceptos impugnados. Veámoslo con más detenimiento. 


\section{LOS PRONUNCIAMIENTOS CONCRETOS DE LAS SSTC $172 / 2020 \mathrm{Y}$ $13 / 2021$}

En contra de muchos de los tipos infractores impugnados se ha esgrimido que vulneran el principio de legalidad administrativa sancionadora del art. 25 $\mathrm{CE}$ en su vertiente de tipicidad. Según los recurrentes, los tipos no permiten a los ciudadanos conocer con certeza qué conductas son constitutivas de infracción administrativa. Sin embargo, el TC en las sentencias no ha declarado vulneración alguna de la garantía de taxatividad, hasta el punto de desestimar todas y cada una de las impugnaciones, tanto del recurso interpuesto por el Parlamento de Cataluña como del planteado por algunos grupos parlamentarios del Congreso.

Por ejemplo, el art. 35.1 LOPSC, que tipifica como infracción muy grave: «Las reuniones o manifestaciones no comunicadas o prohibidas en infraestructuras o instalaciones en las que se prestan servicios básicos para la comunidad o en sus inmediaciones [...]", fue impugnado por los parlamentarios catalanes, que apreciaron en él una vulneración de los principios de tipicidad (art. 25.1 CE) y de seguridad jurídica (art. 9.3 CE) por la inclusión de la expresión «en sus inmediaciones ${ }^{23}$. Sin embargo, el TC no ha considerado que el precepto infrinja los principios de tipicidad y seguridad jurídica ni que su concreción dependa de la decisión prácticamente libre de los órganos administrativos o judiciales, pues, a su parecer, la expresión «en sus inmediaciones» claramente significa «lo que está muy cercano o contiguo a algo"; en este caso, a las infraestructuras e instalaciones en las que se prestan servicios básicos para la comunidad ${ }^{24}$.

Algo similar ha ocurrido con relación al art. 36.1 LOPSC, que tipifica como infracción administrativa grave:

23 También la doctrina criticó la falta de precisión del precepto. Véase J. Ridao Martín (2016), «Las actuales limitaciones sobre la participación política y la libertad de información en el espacio público en España. Una lectura constitucional de la Ley Orgánica 4/2015, de 30 de marzo, de Protección de la Seguridad Ciudadana», Revista Española de Derecho Constitucional, 107, págs. 187-217 (pág. 204) y M. A. Presno Linera, «La expansión del Derecho Administrativo sancionador securitario: análisis constitucional de la Ley Orgánica para la Protección de la Seguridad Ciudadana», en M. L. Cuerda Arnau y J. A. García Amado (dirs.), Protección jurídica del orden público, la paz pública y la seguridad ciudadana (págs. 37-62), Valencia: Tirant lo Blanch (pág. 45).

24 De lo explicado por el Pleno en la STC 13/2021 se deduce que, para que una conducta sea constitutiva de la infracción del art. 35.1 LOPSC, deben concurrir dos requisitos: que se produzca una reunión o manifestación no comunicada o prohibida en infraestructuras o instalaciones en las que se prestan servicios básicos para la comunidad o en un lugar cercano o contiguo a ellas y que, como consecuencia, se obstaculice o altere el normal funcionamiento de los servicios básicos para la comunidad, con causación de riesgo para la vida o la integridad física de las personas. 
«La perturbación de la seguridad ciudadana en actos públicos, espectáculos deportivos o culturales, solemnidades y oficios religiosos u otras reuniones a las que asistan numerosas personas, cuando no sean constitutivas de infracción penal».

Este precepto también fue impugnado únicamente por los parlamentarios de Cataluña, que consideraron que la conducta tipificada, dada su amplitud y falta de concreción, no cumplía los requisitos de certeza y claridad que exige la jurisprudencia constitucional, ya que omite cualquier precisión sobre cuál debe ser el nivel de perturbación que debe tener la actuación infractora y sobre qué resultado debe producirse. Se trata, a juicio de los recurrentes, de una cláusula abierta que permite sancionar como infracción grave cualquier perturbación, incluso una que sea leve ${ }^{25}$. Ante estas alegaciones, la STC 13/2021 advierte que la exigencia de lex certa no se opone a la utilización de un concepto jurídico indeterminado como el de "perturbación de la seguridad ciudadana» en la definición de la conducta infractora, siempre que su concreción sea razonablemente previsible en virtud de criterios lógicos, técnicos o de experiencia. Y, acto seguido, explica que el precepto debe interpretarse, no de forma aislada, sino en el contexto del ordenamiento jurídico en que se inserta con el fin de identificar cuál sea el nivel de perturbación de la seguridad ciudadana que es constitutivo de la conducta infractora y si este comprende o no las alteraciones leves. Para ello, la sentencia delimita esta infracción de los delitos de desórdenes públicos recogidos en los arts. 557 y 558 CP y concluye que el concepto «perturbación de la seguridad ciudadana» no es tan indeterminado como para pugnar con las exigencias de tipicidad, en la medida que hace referencia a cualquier perturbación de ese bien jurídico que no sea constitutiva de delito de desorden público. A ello ańade que, dado que el precepto alude a una "perturbación", para entender cometida la conducta típica no basta con la mera creación de un riesgo para la seguridad ciudadana, sino que es necesario que dicho bien jurídico resulte afectado real y efectivamente. Como consecuencia, el Tribunal Constitucional desestima las impugnaciones de los recurrentes.

La STC 13/2021 también rechaza la supuesta vulneración del principio de tipicidad en que incurría, según la demanda del Parlamento de Cataluña, el art. 36.2 LOPSC al tipificar como infracción la perturbación grave de la seguridad ciudadana producida con ocasión de reuniones o manifestaciones frente a las sedes del Congreso de los Diputados y el Senado. Según los recurrentes, el inciso

25 Idéntica postura comparten en la doctrina J. M. Bilbao Ubillos (2015), «La llamada Ley Mordaza: la Ley Orgánica 4/2015 de Protección de la Seguridad Ciudadana», Teoría y realidad constitucional, 36, págs. 217-260 (pág. 244) y Presno Linera (2016: 46), para el que este precepto es un "cajón de sastre» que permite sancionar como infracción grave cualquier perturbación de la seguridad ciudadana. Por su parte, J. Rodríguez Ten (2015), «Régimen sancionador», en A. Palomar Olmeda (coord.), El nuevo régimen de la seguridad ciudadana (págs. 333-419), Navarra: Aranzadi (págs. 349-350), no ha sido tan crítico con el precepto, pero sí ha reconocido que la expresión «numerosas personas» resulta confusa. 
«frente a las sedes» es una fórmula tan abierta que no cumple con las exigencias del principio de tipicidad ${ }^{26}$. La sentencia insiste en que la tipicidad, como manifestación de la garantía material de la legalidad sancionadora, no se opone al uso de conceptos jurídicos indeterminados en la definición de la conducta punible, siempre que «su concreción sea razonablemente factible en virtud de criterios lógicos, técnicos o de experiencia». En este caso, explica que la expresión «frente a las sedes» es un término equivalente a «enfrente de» o «delante de», por lo que, dada la finalidad de la norma, la manifestación ha de estar próxima a los edificios, ya que sin esa proximidad no parece que se pueda impedir el normal funcionamiento del órgano o llevar a cabo la desconsideración del símbolo que encarnan las sedes (bienes jurídicos protegidos por el precepto).

Por idéntico motivo, la STC 13/2021 desestima la vulneración del principio de tipicidad en que, a juicio de los parlamentarios catalanes, incurría el art. 36.8 LOPSC al tipificar como infracción grave: «La perturbación del desarrollo de una reunión o manifestación lícita, cuando no constituya infracción penal». Según la sentencia, el término "perturbación" también «es un concepto jurídico indeterminado cuya concreción es razonablemente previsible en virtud de criterios lógicos, técnicos o de experiencia», teniendo en cuenta, en este caso, otras normas sancionadoras de la LOPSC (entre otros, los arts. 35.2, 36.2 y 36.3) y ciertos preceptos relevantes del Código Penal (los arts. 557.1 y 557 bis.1.3a).

Tampoco le da la razón la sentencia a los recurrentes catalanes cuando consideran que el art. 36.22 LOPSC constituye una norma sancionadora en blanco que no permite identificar qué tipo de conducta es objeto de sanción. El mencionado precepto tipifica como infracción administrativa grave: «El incumplimiento de las restricciones a la navegación reglamentariamente impuestas a las embarcaciones de alta velocidad y aeronaves ligeras». Pues bien, la STC 13/2021 desestima la impugnación por dos motivos. En primer lugar, porque el precepto hace referencia a un ámbito de actividad muy acotado, como es el relativo al uso de embarcaciones de alta velocidad y aeronaves ligeras (no de cualquier tipo de embarcación o aeronave), y sometido a una regulación que se distingue por su carácter técnico y detallado, contribuyendo con ello a la identificación de la norma remitida. Y, en segundo lugar, porque, dado que el precepto forma parte de la LOPSC, debe entenderse que únicamente tipifica como infracción el incumplimiento de las restricciones a la navegación de embarcaciones de alta velocidad y aeronaves ligeras que se impongan por razones de seguridad pública. En definitiva, la sentencia

$26 \mathrm{Al}$ igual que los recurrentes, en la doctrina también hubo voces que criticaron la inclusión de este concepto jurídico indeterminado. Es el caso de F. Santaolalla López (2014), «El derecho de manifestación ante el Parlamento", Revista de Derecho Político, 91, págs. 13-42: «[...] no es muy seguro qué se entiende por reuniones frente a las sedes parlamentarias: no se define ningún área o perímetro que pueda delimitar este concepto, lo que puede provocar inseguridad a la hora de su aplicación» (pág. 31). En el mismo sentido, véase J. Ridao Martín (2016: 210). 
argumenta que el art. 36.22 LOPSC establece con claridad la esencia de la conducta antijurídica (el incumplimiento de las restricciones a la navegación que se impongan por razones de seguridad pública), remitiendo a los reglamentos todo el desarrollo de las restricciones a la navegación, por lo que descarta toda posible vulneración del principio de legalidad administrativa sancionadora ${ }^{27}$.

También se le imputó la vulneración de la garantía de taxatividad, en conexión con el principio de seguridad jurídica del art. 9.3 CE, al art. 36.23 LOPSC. $\mathrm{El}$ precepto tipifica como infracción administrativa grave: «El uso no autorizado de imágenes o datos personales o profesionales de autoridades o miembros de las Fuerzas y Cuerpos de Seguridad que pueda poner en peligro la seguridad personal o familiar de los agentes, de las instalaciones protegidas o en riesgo el éxito de una operación, con respeto al derecho fundamental a la información». Tanto el recurso del Parlamento catalán como el de los grupos del Congreso argumentaron que al ciudadano medio le resulta imposible saber si captar la imagen o los datos de los agentes puede poner en riesgo el éxito de una operación policial, la seguridad del agente o de su familia o la de las instalaciones protegidas. Sin embargo, la STC 172/2020 (a la que se remite la STC 13/2021) no ha declarado la inconstitucionalidad del precepto, pues, aunque reconoce que podría interpretarse en algunos sentidos claramente contrarios al art. 25.1 CE, decide fijar en el fallo la interpretación que ha de hacerse del mismo para ser acorde a los mandatos constitucionales ${ }^{28}$.

27 Una vez desestimada la vulneración del principio de legalidad, la STC 13/2021 establece cómo debe interpretarse este precepto para ser acorde a la Constitución y aclara que, para entender cometida la infracción, no basta con que tenga lugar el incumplimiento de alguna de las restricciones a la navegación impuestas en aras de garantizar la seguridad pública. Para ello, se requiere, además, que el incumplimiento conlleve un perjuicio o una amenaza concreta para la seguridad ciudadana. Y explica la sentencia que, precisamente aquí, radica la diferencia entre esta infracción y las posibles infracciones previstas en la normativa específica de navegación. Esas infracciones podrán entenderse realizadas por el mero incumplimiento de las restricciones, pues el fin al que sirve ese régimen sancionador es sustentar la gestión ordenada de la navegación. No ocurre lo mismo con el precepto de la LOPSC, con el que se persigue castigar únicamente aquellas actuaciones que se desplieguen en dichos subsectores de actividad que afecten negativamente a la salvaguarda de la seguridad ciudadana.

En primer lugar, sostiene que el «uso» como conducta típica, dado que debe "poner en peligro o en riesgo" alguno de los bienes jurídicos reseńados en el precepto, no se realiza con la mera captación o tenencia de «imágenes o datos personales y profesionales». Solo será sancionable, por tanto, el acto de publicar o difundir de algún modo, sea por medios tradicionales o a través de los cauces que ofrecen las tecnologías de la información y comunicación, como redes sociales u otras plataformas análogas, de tal manera que no bastará la mera captación no seguida de publicación o difusión de tales imágenes o datos. En segundo lugar, afirma que la conducta típica debe conllevar un perjuicio real para la seguridad ciudadana. Y, por último, seńala que la expresión «con respeto del derecho 
Por último, hay que referirse a la infracción prevista en el art. 37.7 LOPSC, que se impugna por su falta de concreción. Este precepto califica como infracción leve:

«La ocupación de cualquier inmueble, vivienda o edificio ajenos, o la permanencia en ellos, en ambos casos contra la voluntad de su propietario, arrendatario o titular de otro derecho sobre el mismo, cuando no sean constitutivas de infracción penal.

Asimismo, la ocupación de la vía pública con infracción de lo dispuesto por la Ley o contra la decisión adoptada en aplicación de aquella por la autoridad competente. Se entenderá incluida en este supuesto la ocupación de la vía pública para la venta ambulante no autorizada».

En relación con la ocupación de inmuebles, viviendas o edificios ajenos (primer párrafo), los recurrentes criticaron que no se concretaba qué ha de entenderse por "ocupación», si hubiera de concurrir violencia o intimidación, o si basta con la simple presencia simultánea de personas en un espacio común, incluso de forma totalmente pacífica. En cuanto a la ocupación de la vía pública (párrafo 2), los recurrentes reprocharon que no se especificaba tampoco la Ley a cuyo incumplimiento se refería el precepto: no se dice si se trata de la propia LOPSC, de la Ley Orgánica del Derecho de Reunión o de cualesquiera otras normas de rango legal o inferior. A su parecer, esta forma de tipificar infracciones y sanciones entraña un cheque en blanco para restringir el ejercicio constitucionalmente protegido del derecho fundamental de reunión.

fundamental a la información» exige que al aplicar el precepto se tenga presente el principio de proporcionalidad y que se realice una ponderación entre el interés público de la difusión y los bienes jurídicos protegidos en el precepto (la seguridad de los agentes, de sus familias, de las instalaciones protegidas y del éxito de las operaciones policiales). Para ello, la sentencia exige la comprobación de si las imágenes o los datos difundidos pertenecen a la vida privada o se relacionan con la actividad oficial de las autoridades o agentes y el examen de qué relevancia pública tiene la difusión de esas imágenes o datos, atendiendo a las circunstancias fácticas y en particular a la presencia o no de un suficiente interés general en conocer esas imágenes o datos. Hasta la entrada en vigor de la LOPSC el TC ha venido considerando, en supuestos de publicación de imágenes de policías, que el derecho a la imagen del agente debía ceder ante el derecho a difundir libremente información veraz, siempre y cuando este se encontrara ejerciendo funciones públicas en un lugar público. Con la entrada en vigor de la LOPSC parece que el panorama ha cambiado y que ya no solo habrá que realizar una ponderación entre el derecho a la información y el derecho a la imagen, sino también entre el derecho a la información y la seguridad ciudadana (o la seguridad de los agentes, de sus familias, de las instalaciones protegidas y de las operaciones policiales). Véase, al respecto, C. Martín Fernández (2019), «El uso no autorizado de imágenes de los miembros de las Fuerzas y Cuerpos de Seguridad", en M. Izquierdo Carrasco y L. Alarcón Sotomayor (dirs.), Estudios sobre la Ley Orgánica de Seguridad Ciudadana (págs. 559-590), Navarra: Aranzadi. 
Las sentencias, sin embargo, rechazan estos argumentos. Por una parte, consideran que se sanciona de forma clara la ocupación de un inmueble ajeno contra la voluntad del propietario o titular de cualquier derecho real, por contraposición a la ocupación constitutiva del delito de allanamiento de morada (art. 202.1 CP) o de domicilio de persona jurídica y establecimiento abierto al público (art. 203.1 y 2 CP), del delito de usurpación (art. 245.2 CP) o del delito de desórdenes públicos con ocupación de domicilio de persona jurídica pública o privada (art. 557 ter.1 CP). Además, argumentan que se requiere claramente la ausencia de violencia, pues de concurrir la misma daría entrada a las formas agravadas de los tipos penales ${ }^{29}$. En consecuencia, no se aprecia irregularidad alguna en la primera infracción del art. 37.7 con relación al principio de tipicidad. Y, por otra parte, las sentencias declaran que la remisión a «lo dispuesto por la Ley» del segundo párrafo del precepto va referida claramente a normas con rango legal, de suerte que las previsiones que se contengan en cada ley sectorial remitida concurren a complementar los elementos esenciales de la conducta antijurídica, por lo que tampoco en este sentido se detecta vulneración alguna del principio de legalidad.

En definitiva, el Pleno del TC ha rechazado en estas sentencias que las infracciones impugnadas sean inconstitucionales y las ha interpretado de forma que resultan plenamente conformes a los mandatos constitucionales. A este respecto, la magistrada Balaguer Callejón ha criticado en su voto particular a la STC 172/2020 que este tipo de pronunciamientos —interpretativos y resultado de la aplicación de los principios de conservación de la ley y de interpretación conforme a la Constitución-, "pueden no ser siempre compatibles con la garantía de la seguridad jurídica (art. 9.3 CE) y, tratándose de derecho sancionador, con las garantías de tipicidad y taxatividad (legalidad sancionadora art. 25.1 CE)». En mi opinión, sin embargo, las sentencias interpretativas son fundamentales para contribuir a la seguridad jurídica de los ciudadanos, dada la irremediable relatividad de la supuestamente «absoluta» garantía de tipicidad. Precisamente en esto último paso a centrarme.

\section{LA RELATIVIDAD DEL PRINCIPIO DE TIPICIDAD}

El TC viene destacando que el principio de legalidad que el art. $25 \mathrm{CE}$ consagra para el derecho administrativo sancionador comporta una doble garantía: una material y otra formal ${ }^{30}$. La material es la relativa a la tipicidad; la formal a la

29 En este sentido, véase R. Pizarro Nevado (2018), «De la ineficaz e inadecuada tutela del patrimonio inmobiliario privado en la Ley Orgánica de Protección de la Seguridad Ciudadana», Revista General de Derecho Administrativo, 49, págs. 1-39.

30 Lo viene sosteniendo desde la STC 42/1987, de 7 de abril: «El art. 25.1 de la Constitución prescribe que «nadie puede ser condenado o sancionado por acciones y omisiones que en el momento de producirse no constituyan delito, falta o infracción administrativa, según la 
reserva de ley. No nos ahorran estas sentencias sobre la LOPSC esas afirmaciones que reiteran, aunque algo más brevemente. En cualquier caso, lo que quiero destacar es que repiten también la afirmación de que, frente a la garantía formal de la reserva de ley, de la que se dice que es «relativa o limitada » $^{31}$, la material, esto es, la de la tipicidad, taxatividad o lex certa, tiene «alcance absoluto». Pero, por mucho que lo diga el TC, ese «alcance absoluto» es, permítaseme el oxímoron, muy relativo ${ }^{32}$.

Lo es por la misma naturaleza de la exigencia de que se trata: la certeza de una ley (y, en realidad, de toda proposición) es algo inevitablemente graduable

legislación vigente en aquel momento». El derecho fundamental así enunciado incorpora la regla nullum crimen nulla poena sine lege, extendiéndola incluso al ordenamiento sancionador administrativo, y comprende una doble garantía. La primera, de orden material y alcance absoluto, tanto por lo que se refiere al ámbito estrictamente penal como al de las sanciones administrativas, refleja la especial trascendencia del principio de seguridad en dichos ámbitos limitativos de la libertad individual y se traduce en la imperiosa exigencia de predeterminación normativa de las conductas ilícitas y de las sanciones correspondientes. La segunda, de carácter formal, se refiere al rango necesario de las normas tipificadoras de aquellas conductas y reguladoras de estas sanciones, por cuanto, como este Tribunal ha señalado reiteradamente, el término «legislación vigente» contenido en dicho art. 25.1 es expresivo de una reserva de Ley en materia sancionadora».

Lo han reiterado después muchas otras sentencias. Por todas, STC 150/2020, de 22 de octubre.

31 Afirma la STC 219/1989, de 21 de diciembre: «Esta segunda garantía, que alude a una reserva de Ley en materia punitiva, sólo tiene, sin embargo, una eficacia relativa o limitada en el ámbito de las sanciones administrativas, por razones que atañen al modelo constitucional de distribución de las potestades públicas, al carácter en cierto modo insuprimible de la potestad reglamentaria en dicho ámbito y a otras consideraciones de prudencia o de oportunidad».

De similar forma se pronuncian muchas sentencias posteriores. Por todas, STC 160/2019, de 12 de diciembre.

32 De hecho, así parece aceptarlo con carácter general en la STC 69/1989, de 20 de abril: «[...] si bien los preceptos, legales o reglamentarios, que tipifiquen las infracciones deben definir con la mayor precisión posible los actos, omisiones o conductas sancionables, no vulnera la exigencia de lex certa que incorpora el art. 25.1 de la Constitución la regulación de tales supuestos ilícitos mediante conceptos jurídicos indeterminados, siempre que su concreción sea razonablemente factible en virtud de criterios lógicos, técnicos o de experiencia y permitan prever, por consiguiente, con suficiente seguridad, la naturaleza y las características esenciales de las conductas constitutivas de la infracción tipificada, pues, como ha declarado este Tribunal en reiteradas ocasiones (STC 62/1982, de 15 de octubre, ATC 703/1985, de 16 de octubre, entre otras resoluciones), dado que los conceptos legales no pueden alcanzar, por impedirlo la propia naturaleza de las cosas, una claridad y precisión absolutas, es necesario en ocasiones un margen de indeterminación en la formulación de los tipos ilícitos que no entra en conflicto con el principio de legalidad, en tanto no aboque a una inseguridad jurídica insuperable con arreglo a los criterios interpretativos antes enunciados». 
y los conceptos que emplea, salvo raras excepciones, admiten matices y variadas interpretaciones. $\mathrm{Y}$ es prácticamente imposible hacer las normas (incluidas las punitivas) de otra forma, igual que es casi imposible hablar o escribir de manera diversa. Lo que exige este principio, en cuanto a las conductas infractoras, es un cierto grado de certeza y lo que prohíbe es no alcanzarlo. Y la línea divisoria es en sí misma muy indeterminada y borrosa. Y, en lo concerniente al castigo correspondiente, lo que impone el principio no es que la ley lo predetermine exactamente en su contenido y extensión, sino que marque un máximo y un mínimo con un intervalo que no supere ciertos límites que también son imprecisos. Y eso es así no solo en el derecho administrativo sancionador, sino en el mismo derecho penal. Esto no solo es una obviedad comprobable a la vista de infinidad de preceptos punitivos, sino que lo demuestra palmariamente la propia jurisprudencia del TC. De hecho, es difícil saber de antemano y a ciencia cierta si normas punitivas con cierto grado de indeterminación superarán o no su control de constitucionalidad, o sea, si se entenderá que su indeterminación permanece dentro de unos límites tolerables o los supera.

El interés de las sentencias del Tribunal Constitucional aquí comentadas no está en sus declaraciones generales sobre la relatividad de la exigencia de predeterminación normativa de la conducta y de la sanción. A este respecto, más bien solo repite que lo que exige este principio es que el legislador debe hacer el «máximo esfuerzo posible» en la tipificación (lo que es de una extraordinaria vaguedad) y que se admiten conceptos jurídicos indeterminados con ciertos límites extremos. En nada de esto hay novedad, aunque, bien mirado, ya es suficiente para desvirtuar el supuesto "alcance absoluto» de esta exigencia. El interés de estas sentencias del TC en lo atinente a la tipicidad está en su aplicación, como ha podido observarse. En buena medida lo que imputaban los recurrentes a varios de los preceptos que impugnaban era su indeterminación que reputaban violadora del art. $25 \mathrm{CE}$ por no acomodarse al principio de tipicidad. Y si realmente tuviera «alcance absoluto» no les faltaría razón. Con ese canon de constitucionalidad, al que da pábulo la altisonante proclamación jurisprudencial sobre el «alcance absoluto» del requisito de tipicidad o taxatividad, buena parte de los preceptos de la LOPSC no lo superarían. Pero, en realidad, no solo ellos, sino otros muchísimos de las más diversas leyes sancionadoras y hasta otros muchos del Código Penal. La verdad es que si estas sentencias del TC salvan los preceptos impugnados es porque admiten con notable amplitud la relativización de la exigencia. Y esta manga ancha del TC se ha visto por igual en otras muchas ocasiones. Es inevitable. Es incluso difícil formular en términos más concretos lo que realmente exige el TC, la indeterminación de los tipos que está dispuesto a admitir y la que ya considera intolerable. Aun dentro de esa dificultad inevitable, las sentencias comentadas patentizan una vez más la notable relajación del supuesto "carácter absoluto».

Cosa distinta es que, ante cada aplicación de las normas sancionadoras de la LOPSC, habrá que proscribir las interpretaciones desviadas y, en especial, 
las extensivas que superen lo que razonablemente cabe incluir en ellas o lo que suponga castigar conductas que realmente no constituyan lesión o peligro de la seguridad ciudadana. Esto es, la flexibilización del principio de tipicidad como mandato al legislador es sin perjuicio de su función de mandato al aplicador de las normas. Es más, a medida que se relativiza la exigencia de tipicidad al legislador hay que ser más puntilloso en su exigencia al aplicador de esas normas, en parte para evitar que las normas sancionadoras puedan desalentar el ejercicio de ciertos derechos fundamentales, como se verá en el siguiente epígrafe. Quizá esto sea especialmente necesario ante las normas sancionadoras de la LOPSC porque el peligro de que se usen de forma inadecuada y de que, con ello, se desincentive el ejercicio de ciertos derechos fundamentales es particularmente intenso. Además, frente a esos peligros es antídoto espléndido el art. 4.1 in fine, según el cual todas las normas sancionadoras de la LOPSC «deberán interpretarse y aplicarse del modo más favorable a la plena efectividad de los derechos fundamentales y libertades públicas». Pero, admitido esto sin ambages, hay que reconocer la relativización de la exigencia de predeterminación normativa, como lo hacen las sentencias comentadas.

\section{LOS PRONUNCIAMIENTOS DE LAS SENTENCIAS SOBRE LAS INFRACCIONES RELATIVAS AL DERECHO DE REUNIÓN. EL ESCASO PROTAGONISMO DE LA DOCTRINA DEL EFECTO DESALIENTO}

Las mayores diatribas vertidas contra la ley y que han sido responsables del calificativo de «ley mordaza» han consistido en afirmar que se trata de una ley que reprime y limita en exceso el ejercicio del derecho fundamental de reunión. La polémica se acentúa por la propia naturaleza del derecho en cuestión, pues entre los derechos fundamentales reconocidos por la Constitución destaca el derecho de reunión, esencial en toda sociedad democrática. Como explica Torres Muro «el intercambio de ideas y la expresión de las mismas que suponen ambas formas de reunirse y manifestar son imprescindibles para que se produzca el libre flujo de opiniones que aparece como básico para el buen funcionamiento de un Estado democrático» ${ }^{33}$. De hecho, según muchas de las

33 I. Torres Muro (1991), El derecho de reunión y manifestación, Madrid: Civitas (pág. 21). En este sentido, véase también J. M. Goig Martínez (2012), «El molesto derecho de manifestación», Revista de Derecho UNED, 11, págs. 353-386 (pág. 361) y Ridao Martín (2016: 200). Precisamente por la importancia de este derecho, el mantenimiento del orden público durante las reuniones o manifestaciones es una de las tareas policiales más complejas, pues, como explica E. Blay Gil (2013), «El control policial de las protestas en España", Indret: Revista para el Análisis del Derecho, 4, págs. 1-32, «la tensión entre libertad y seguridad en la que opera la policía es particularmente 
voces críticas, este relevante derecho fundamental se encuentra en entredicho con la entrada en vigor de la LOPSC. Incluso en la doctrina, algunos autores han advertido en la LOPSC una tendencia "casi obsesiva" a tipificar conductas relacionadas con la protesta ciudadana ${ }^{34}$, llegando a afirmar que "está conectada con el movimiento ley y orden, y entronca no con la tutela de nuevos bienes que han de ser protegidos, sino con la vieja represión de ciertos movimientos sociales» ${ }^{35}$. Algunos hasta sostienen que la nueva LOPSC convierte en impracticable el derecho de reunión y manifestación, diseñando un modelo de tolerancia cero respecto al derecho a la protesta ${ }^{36}$.

Esto ha tenido su eco en los recursos de inconstitucionalidad interpuestos. Muchos de los tipos infractores impugnados guardan relación con el derecho de reunión (arts. 35.1, 36.2, 36.8, 37.1 y 37.3 LOPSC). En líneas generales, los recurrentes aprecian que el derecho fundamental se restringe demasiado mediante la tipificación de ciertas infracciones y que algunas de ellas provocan chilling effect en el ejercicio de ese derecho. Veámoslo con más detenimiento, pero antes conozcamos en qué consiste la doctrina del efecto desaliento.

\section{LA DOCTRINA DEL EFECTO DESALIENTO O CHILLING EFFECT}

Esta doctrina «tiene su origen en la jurisprudencia norteamericana de mediados del siglo pasado (chilling effect), cuyo ámbito de aplicación se limitaba, en un primer momento, a los casos en que se veía afectado el derecho a la libertad de expresión» ${ }^{37}$. Con el transcurso del tiempo se ha ido aplicando con relación a

evidente en este contexto, en el que debe encontrarse un difícil equilibrio entre la protección del orden legal y la defensa de los derechos de los ciudadanos a la libertad de expresión y de reunión» (pág. 4).

34 Es el caso de A. Alonso Rimo (2014), «El nuevo Anteproyecto de Ley Orgánica de Protección de la Seguridad (¿Ciudadana?): análisis desde la perspectiva del derecho de reunión y manifestación", Revista General de Derecho Penal, 21, págs. 1-38 (pág. 11).

35 Presno Linera (2016: 38). De igual forma se pronunció el autor cuando la LOPSC solo era un anteproyecto. Véase M. A. Presno Linera (2014), «El primer Anteproyecto de Ley Orgánica para la protección de la seguridad ciudadana», Teoría y realidad constitucional, 34, págs. 269-292 (pág. 272).

36 G. Portilla Contreras (2016), «La contrarrevolución preventiva emprendida por el Derecho Penal y Administrativo para hacer frente a los movimientos de protesta y desobediencia civil», en M. L. Cuerda Arnau y J. A. García Amado (dirs.), Protección jurídica del orden público, la paz pública y la seguridad ciudadana (págs. 63-82), Valencia: Tirant lo Blanch (págs. 65 y 73); y M. F. Massó Garrote (2016), «El derecho de reunión y manifestación en el nuevo marco regulatorio de la Ley de Protección de Seguridad Ciudadana (LO 4/2015 de 30 de marzo)», Estudios de Deusto, 64, 2, págs. 101-126 (pág. 102).

37 D. Colomer Bea (2019), «La doctrina del efecto desaliento como punto de conexión entre el Derecho penal y los derechos fundamentales», Cuadernos Electrónicos de Filosofía del 
otros derechos fundamentales ${ }^{38}$. Pero continúa siendo la libertad de expresión el ámbito en el que con más frecuencia se ha acudido a esta doctrina ${ }^{39}$.

Según la ciencia estadounidense, lo que esta teoría trata de evitar es que cualquier conducta amparada por un derecho fundamental y que pueda resultar beneficiosa para la sociedad y el interés general pueda ser desalentada por cualquier medida administrativa que, en origen, no tiene como finalidad regular esa específica conducta ${ }^{40}$. A modo ilustrativo, Schauer dice que se causaría efecto desaliento si una norma sobre la pornografía tuviera el efecto de disuadir la publicación del Decamerón o si una norma que pretende castigar la publicación de falsedades termina por desalentar la publicación de hechos verídicos o de opiniones. Y señala que, a mayor gravedad del castigo previsto, mayor efecto desaliento se genera. Para explicar el surgimiento de este efecto «escalofriante», el autor reflexiona acerca de la utopía que supone tratar de alcanzar un nivel pleno de seguridad jurídica sobre aquello que resulta sancionado y, especialmente, sobre los límites de las conductas que constituyen un ilícito, y concluye atribuyendo la responsabilidad de la generación de este efecto desaliento a la vaguedad terminológica que, en ocasiones - y muchas veces sin otra alternativa-, emplea la legislación para tipificar ilícitos. Tras ello, Schauer finaliza reconociendo que toda norma sancionadora creará cierto efecto desaliento, aunque sea mínimo, para alguien en algún lugar, pues resulta imposible reducir a cero la incertidumbre generada, por lo que concluye que solo aquellos casos más graves serán los que verdaderamente haya que evitar por el riesgo que entrañan para los derechos fundamentales ${ }^{41}$.

Esta doctrina ha sido aplicada por el TEDH en varios asuntos, sobre todo, con relación a la libertad de expresión y a la libertad de reunión y de asociación de los arts. 10 y $11 \mathrm{CEDH}$. En la mayoría de las sentencias, el TEDH exige una estricta aplicación del principio de proporcionalidad cuando existe el riesgo de que los castigos impuestos por la autoridad nacional sean capaces de desincentivar el ejercicio de derechos fundamentales ${ }^{42}$. También nuestro TC se ha hecho

Derecho, 41, págs. 97-116 (pág. 102).

38 Como puede ser el derecho a no autoinculparse o el derecho al debido proceso. A este respecto, véase Columbia Law Review (1969), «The Chilling Effect in Constitutional Law», Columbia Law Review, vol. 69, 5, págs. 808-842.

39 F. Schauer (1978), «Fear, Risk and the First Amendment: Unraveling the Chilling Effect», Boston University Law Review, 58, págs. 685-732 (pág. 685).

40 Schauer (1978: 693) sostiene: «A chilling effect occurs when individuals seeking to engage in activity protected by the first amendment are deterred from so doing by governmental regulation not specifically directed at that protected activity». Como vemos, el autor incluso restringe la utilización de la doctrina del efecto desaliento a los casos en los que se ejerce la libertad de expresión, de prensa o de reunión.

41 Schauer (1978: 694-701).

42 Véanse, entre otras, las SSTEDH de 20 de mayo de 1999, asunto Bladet Tromsø and Sten- 
eco de esta doctrina. Su primera aplicación fue un tanto polémica, pues conllevó la excarcelación de algunos miembros del ilegalizado partido político Herri Batasuna que fueron condenados por colaborar con la banda terrorista ETA ${ }^{43}$. Pero, con posterioridad, han sido varias las ocasiones en las que el TC ha seguido aplicando esta doctrina ${ }^{44}$. A decir verdad, se ha venido utilizando siempre en el

saas contra Noruega; de 21 de marzo de 2002, asunto Nikula contra Finlandia; de 15 de diciembre de 2005, asunto Kyprianou contra Chipre; de 3 de mayo de 2007, asunto Baczkowski y otros contra Polonia; de 15 de noviembre de 2007, asunto Galstyan contra Armenia; de 21 de julio de 2011, asunto Heinisch contra Alemania; de 3 de octubre de 2013, asunto Kasparov y otros contra Rusia; de 15 de mayo de 2014, asunto Taranenko contra Rusia; de 14 de octubre de 2014, asunto Yilmaz Yildiz y otros contra Turquía; y de 15 de octubre de 2015, asunto Gafgaz Mammadov contra Azerbaiyán.

Se trata de la STC 136/1999, de 20 de julio, que supuso la excarcelación de los miembros de la Mesa Nacional de Herri Batasuna, que fueron condenados por colaborar con ETA por difundir vídeos en los que la banda terrorista explicaba sus propuestas para acabar con el conflicto existente en el País Vasco. Al parecer del TC, en el caso enjuiciado se produjo «una vulneración del principio de legalidad penal en cuanto comprensivo de la proscripción constitucional de penas desproporcionadas, como directa consecuencia de la aplicación del art. 174 bis a) CP 1973». Según la sentencia, el precepto era inconstitucional porque no permitía atemperar la sanción penal de prisión mayor a la entidad de los actos de colaboración con banda armada, desincentivando con ello el ejercicio del derecho fundamental a la libertad de expresión, pues, aunque la difusión de los vídeos de ETA constituía una conducta claramente ilícita y ajena al ejercicio de la libertad de expresión, en puridad formaba parte de su ámbito material y era muy próxima al ámbito jurídicamente protegido. Para un estudio más profundo de esta sentencia, véase T. de Domingo Pérez (2003), «La argumentación jurídica en el ámbito de los derechos fundamentales: en torno al denominado "chilling effect» o "efecto desaliento»", Revista de Estudios Politicos, 122, págs. 141-166 (págs. 142-156).

44 Es el caso de la STC 110/2000, de 5 de mayo, en la que se otorga el amparo solicitado por el recurrente y se anula la sentencia del juez de lo penal que lo condenó como reo de un delito de desacato. El recurrente escribió un artículo de opinión en un periódico criticando la actitud de un alcalde y, aunque la sentencia reconoce cierto tono acerbo e incluso hiriente, considera finalmente que «la conducta enjuiciada no fue sino legítimo ejercicio de las libertades de expresión e información». Para llegar a esta conclusión, el TC recuerda la doctrina del efecto desaliento: «[...] cuando un órgano judicial aplica una norma penal como la analizada, que se refiere a conductas en las que se halla implicado el ejercicio de un derecho fundamental (en nuestro caso, del reconocido por el art. 20.1 CE), ha de tener presente el contenido constitucional del derecho de que se trate, es decir, el haz de garantías y posibilidades de actuación o resistencia que otorga. De modo que, en este caso, ni puede incluir entre los supuestos sancionables aquellos que son ejercicio de la libertad de expresión o información, ni puede interpretar la norma penal de forma extensiva, comprendiendo en la misma conductas distintas de las expresamente previstas, pues en virtud de su conexión con el derecho fundamental la garantía constitucional de taxatividad ex art. 25.1 CE deviene aún más reforzada. [...] tampoco puede el Juez, al aplicar la norma penal (como no puede el legislador al definirla), reaccionar desproporcionadamente frente 
ámbito penal, pero no creo que exista obstáculo alguno para aplicarla también en el ámbito administrativo sancionador, donde las sanciones son, en ocasiones, más gravosas que muchas penas previstas en el Código Penal. Y menos desde la supresión de las faltas en nuestro ordenamiento y la conversión de muchas de ellas en infracciones administrativas ${ }^{45}$.

Sea como fuere, de la jurisprudencia puede concluirse que la doctrina del efecto desaliento contempla dos garantías: una relativa al ilícito, que exige su adecuada tipificación; y otra respecto al castigo, que impone su más absoluta proporcionalidad.

Por una parte, el efecto desaliento guarda estrecha relación con el principio de tipicidad, pues surge cuando la conducta constitutiva de infracción, rayana en el ejercicio legítimo de un derecho fundamental, no está del todo clara y puede temerse ejercer dicho derecho por si se incurre en el ilícito. Sensu contrario, esta doctrina exige que todas las normas que tipifiquen como infracción una conducta próxima al ejercicio de un derecho fundamental sean lo más claras y precisas posible, de modo que los ciudadanos sepan en todo momento cuándo se está ejerciendo legítimamente el derecho o se está incurriendo en un ejercicio extralimitado susceptible de ser castigado. No obstante, de nuevo es necesario advertir que, por mucho que el TC declare la garantía material de tipicidad como una exigencia absoluta, en realidad no es posible, y ni siquiera deseable, que las normas que tipifican infracciones sean absolutamente precisas. Lo impide la naturaleza

al acto de expresión, ni siquiera en el caso de que no constituya legítimo ejercicio del derecho fundamental en cuestión y aun cuando esté previsto legítimamente como delito en el precepto penal».

En términos similares, se pronuncian las SSTC 88/2003, de 19 de mayo, 185/2003, de 27 de octubre, y 108/2008, de 22 de septiembre, aunque con relación al derecho a la libertad de acción y afiliación sindical. Por último, es destacable la STC 140/2016, de 21 de julio, pues aplica la doctrina del efecto desaliento con relación al derecho de acceso a la tutela jurisdiccional y permite, así, apreciar que, aunque inicialmente esta doctrina fue concebida para evitar el desaliento de los derechos fundamentales a la libertad de expresión y reunión, en realidad, parece poder aplicarse con relación a todos los derechos fundamentales. En el caso enjuiciado por esta última sentencia, los demandantes sostenían que la Ley 10/2012, de 20 de noviembre, por la que se regulan determinadas tasas en el ámbito de la Administración de Justicia, imponía unas tasas que podían comportar una medida de efectos inhibidores o disuasorios del acceso a la justicia. El TC les dio la razón y estimó el recurso de inconstitucionalidad interpuesto, por considerar que «en nuestro Estado social y democrático de Derecho, el cual propugna entre otros valores superiores de su ordenamiento jurídico la justicia y la igualdad (art. 1.1 CE), el pago de un tributo no puede obstaculizar el ejercicio de un derecho fundamental».

En sentido contrario, véase D. A. Cuesta Bárcena (2021), «Las reuniones y manifestaciones en lugares públicos como infracciones administrativas de la Ley Orgánica de Protección de la Seguridad Ciudadana (reflexiones en torno a la STC 172/2020, de 19 de noviembre)», Revista Española de Derecho Administrativo, 210, págs. 185-224 (págs. 191 у 217). 
de las cosas y sería poco operativo. Por ello, es esencial el papel del aplicador de las normas. Tanto la Administración como los jueces deben interpretarlas de un modo favorable a los derechos fundamentales para así evitar el indeseable chilling effect. En este sentido, ya he advertido que el art. 4.1 in fine LOPSC juega un importante rol, pues exige interpretar las infracciones de la LOPSC de modo favorable a estos derechos.

Por otra parte, dado que a mayor castigo mayor efecto disuasorio, esta doctrina exige aplicar de forma radical el principio de proporcionalidad en los casos de conductas ilícitas próximas al ejercicio legítimo de un derecho fundamental. No se trata de no sancionar. Se trata de sancionar en una medida menos gravosa a como se castigan las conductas ajenas al ejercicio de los derechos fundamentales, pues castigar de forma excesiva una conducta limítrofe a este ejercicio podría conllevar un efecto desaliento ${ }^{46}$.

Habría que concluir, por tanto, que, en nuestro caso, para apreciar un efecto desaliento en el ejercicio del derecho de reunión como consecuencia de la tipificación de las infracciones de la LOPSC, los tipos infractores deberían ser oscuros y las sanciones previstas (o aplicadas en el caso concreto) desproporcionadas. Sin embargo, como veremos a continuación, el TC no ha apreciado ninguna de estas circunstancias.

\section{LOS PRONUNCIAMIENTOS SOBRE LAS INFRACCIONES IMPUGNADAS VINCULADAS AL DERECHO FUNDAMENTAL DE REUNIÓN}

Ya he advertido en el epígrafe anterior que el TC ha desestimado todas las impugnaciones de los recurrentes consistentes en que las infracciones de la LOPSC vulneraban el principio de tipicidad. Pues bien, en parte por esto, las sentencias también han desestimado aquellas otras impugnaciones basadas en la doctrina del efecto desaliento. No obstante, las infracciones relativas al derecho de reunión también han sido recurridas por restringir este derecho de forma injustificada, por lo que merece la pena detenerse a estudiar las alegaciones de los recurrentes y la respuesta que han recibido del máximo intérprete de la Constitución ${ }^{47}$.

En primer lugar, con relación al art. 36.2 LOPSC, que tipifica como infracción grave la perturbación grave de la seguridad ciudadana que se produzca con ocasión de reuniones o manifestaciones frente a las sedes del Congreso de los Diputados, el Senado y las asambleas legislativas autonómicas, los recurrentes apreciaron una restricción desmedida del ejercicio del derecho de reunión del art. $21 \mathrm{CE}$ porque no estimaban justificado que se protegiera a las cámaras par-

46 Para conseguir esa estricta proporcionalidad y evitar que se desincentive el ejercicio de un derecho fundamental, hay quien propone como solución aplicar en estos casos la eximente incompleta de ejercicio de un derecho del art. 21.1 CP. Véase Colomer Bea (2019: 105).

47 Esto mismo es estudiado de forma detallada por Cuesta Bárcena (2021: 185-224). 
lamentarias cuando no se encontraran reunidas ${ }^{48}$. Por el contrario, la sentencia sí que considera susceptible de protección tanto el funcionamiento de las Cámaras como su mera relevancia institucional, la cual también puede ponerse en entredicho aunque estén vacías ${ }^{49}$. El motivo lo explica la STC 172/2020, y lo reitera la STC 13/2021, y consiste en que las sedes parlamentarias «revisten una doble transcendencia que las hace dignas de protección jurídica. Por un lado, albergan el desenvolvimiento efectivo de las funciones representativas por medio del funcionamiento del órgano legislativo en sus distintas formas y composiciones. Por otro lado, resulta inherente a ellas, incluso cuando están inactivas, su carácter de representación institucional de la voluntad popular, de modo que constituyen un símbolo del más alto valor constitucional». Como consecuencia, las sentencias niegan que el derecho fundamental se vea indebidamente restringido.

Además de lo anterior, la demanda del Parlamento de Cataluña añade que se trata de un tipo excesivamente abierto que puede desincentivar indebidamente el ejercicio del derecho fundamental del art. $21 \mathrm{CE}$. Sin embargo, tal y como he señalado en el epígrafe relativo al principio de tipicidad, la STC 13/2021 aprecia

48 En sentido similar, véase Presno Linera (2016: 46): «no queda claro qué es lo que se pretende tutelar cuando se sancionan con tanta gravedad reuniones o manifestaciones ante las sedes parlamentarias cuando las Cámaras no estén reunidas». Tampoco Bilbao Ubillos (2015: 245) alcanza a comprender «el motivo de esa protección singular, privilegiada, de unos edificios oficiales». Por su parte, Massó Garrote (2016: 120) directamente intuye la reprochable finalidad de no permitir la visibilización «del malestar social ante los órganos representativos de la ciudadanía».

No opina lo mismo Balaguer Callejón. La magistrada discrepante no cree que la simbología de las Cortes deba priorizarse sobre el ejercicio del derecho de manifestación y reunión. Por eso, afirma en su voto particular a la STC 172/2020 que «resulta evidente la inconstitucionalidad del precepto impugnado cuando cualifica el comportamiento punible por el mero hecho de que se produzca ante las cámaras cerradas. Porque en este caso no hay función parlamentaria que preservar. Y la preservación del símbolo no basta para justificar la restricción del derecho, porque la dignidad se predica de los seres humanos, titulares de los derechos fundamentales (art. 10.1 CE) y no de las instituciones o de los edificios en que estas se albergan». Creo que los principios que mueven a la magistrada a emitir su voto particular son loables. Pero no me parece que en este caso se priorice el mero valor institucional de los edificios que albergan las Cámaras legislativas sobre el efectivo ejercicio del derecho de reunión. Lo que verdaderamente se prioriza sobre su ejercicio es la seguridad ciudadana, pues solo cuando se produce una perturbación grave a la misma se comete la infracción. Así lo sostiene L. Alarcón Sotomayor (2019), «Derecho penal y derecho sancionador de la seguridad ciudadana. El proceso despenalizador», en M. Izquierdo Carrasco y L. Alarcón Sotomayor (dirs.), Estudios sobre la Ley Orgánica de Seguridad Ciudadana (págs. 301-348), Pamplona: Aranzadi, que considera que «el art. 36.2 LOPSC no tipifica sin más las reuniones o manifestaciones de los ciudadanos realizadas frente a las sedes del Congreso y el Senado, sino únicamente esas reuniones cuando hayan generado una perturbación grave de la seguridad ciudadana» (pág. 325). 
que se trata de un precepto que respeta la mencionada garantía y que, por tanto, no desalienta el ejercicio del derecho de reunión.

En segundo lugar, la demanda del Parlamento reprocha que la conjunción de los arts. 37.1 y 30.3 LOPSC afecta a la propia esencia del ejercicio del derecho de reunión porque en su virtud pueden ser sancionados quienes simplemente hayan participado en una concentración espontánea o que no haya sido previamente comunicada (como es el caso de meros participantes que, sin haber intervenido en la organización o convocatoria, lleguen a portar banderas, pancartas, signos, coreen consignas o hagan uso de la megafonía) ${ }^{50}$.

El art. 37.1 LOPSC tipifica como infracción leve:

La celebración de reuniones en lugares de tránsito público o de manifestaciones, incumpliendo lo preceptuado en los artículos 4.2, 8, 9, 10 y 11 de la Ley Orgánica 9/1983, de 15 de julio, cuya responsabilidad corresponderá a los organizadores o promotores.

Y el art. 30.3 LOPSC establece:

«A los efectos de esta Ley se considerarán organizadores o promotores de las reuniones en lugares de tránsito público o manifestaciones las personas físicas o jurídicas que hayan suscrito la preceptiva comunicación. Asimismo, aun no habiendo suscrito o presentado la comunicación, también se considerarán organizadores o promotores quienes de hecho las presidan, dirijan o ejerzan actos semejantes, o quienes, por publicaciones o declaraciones de convocatoria de las mismas, por las manifestaciones orales o escritas que en ellas se difundan, por los lemas, banderas $\mathrm{u}$ otros signos que ostenten o por cualesquiera otros hechos pueda determinarse razonablemente que son directores de aquellas».

Pues bien, la STC 172/2020 rechaza dicha interpretación y sostiene que lo que sucede más bien es todo lo contrario; es decir, que el precepto impugnado acota o restringe la responsabilidad sancionadora. Así lo consideran también en la doctrina algunos autores, que aluden a una función reductora de la responsabili$\operatorname{dad}^{51}$. Es el caso de Rebollo, que considera que este tipo de fórmulas «delimitan quiénes pueden ser considerados responsables de entre aquellos que intervengan

50 También algunos autores se pronunciaron en este sentido. Véase J. Baucells Lladós (2015), «El nuevo 'Derecho sancionador autoritario'. Acerca de la inconstitucionalidad del Código Penal y la Ley de Protección de la Seguridad Ciudadana", Revista General de Derecho Penal, 24, págs. 1-38 (pág. 33).

51 A este respecto, véase M. Rebollo Puig (2014), «Responsabilidad de los autores de las infracciones y de los partícipes», Revista Vasca de Administración Pública, 99-100, págs. 2527-2546 (págs. 2542-2543); A. Huergo Lora (2019), «Los sujetos responsables de las infracciones en materia de seguridad ciudadana», en M. Izquierdo Carrasco y L. Alarcón Sotomayor (dirs.), Estudios sobre la Ley Orgánica de Seguridad Ciudadana (págs. 435-458), Pamplona: Aranzadi (pág. 450); y M. Gómez Tomillo e I. Sanz Rubiales (2017), Derecho Administrativo sancionador: Parte General, 4a ed., Pamplona: Aranzadi (pág. 551). 
culpablemente en la infracción; de entre aquellos que materialmente pudieran ser considerados autores o partícipes como colaboradores ${ }^{52}$.

Yo tampoco creo que surjan problemas en este aspecto ${ }^{53}$. El art. 4.2 LODR responsabiliza del buen orden de las reuniones y manifestaciones a sus organizadores, a los que exige que adopten las medidas necesarias para su adecuado desarrollo. De hecho, el art. 9 LODR, que regula el contenido de la comunicación previa que debe presentarse a la autoridad para la celebración de una reunión en un lugar de tránsito público o de una manifestación, establece como información a hacer constar en el escrito de comunicación las «medidas de seguridad previstas por los organizadores o que se soliciten de la autoridad gubernativa». De esta forma, a través de la comunicación previa, los organizadores o promotores asumen el compromiso de adoptar las medidas de seguridad a las que hayan hecho alusión en su escrito. Pues bien, como la conducta típica consiste en incumplir una serie de obligaciones que la LODR impone a los organizadores o promotores de la reunión o manifestación, es lógico que sean estos los responsables (si actuaron con dolo o culpa) y no los demás participantes ${ }^{54}$. Ello sería contrario al

52 Rebollo Puig (2014: 2543).

53 Sí surgían inconvenientes con la redacción del Anteproyecto de LOPSC. El art. 29.3 preveía: «En los supuestos en que proceda de conformidad con la descripción de los tipos infractores serán responsables, junto con quienes realicen los hechos: [...]. c) Las personas físicas o jurídicas convocantes de reuniones en lugares de tránsito público y manifestaciones, así como quienes de hecho las presidan, dirijan o ejerzan actos semejantes, o quienes por publicaciones o declaraciones de convocatoria de las mismas, por las manifestaciones orales o escritas que en ellas se difundan, por los lemas, banderas u otros signos que ostenten o por cualesquiera otros hechos, pueda determinarse razonablemente que son directores o inspiradores de aquéllas».

Tanto el CGPJ, en su informe de 27 de marzo de 2014 al Anteproyecto de Ley Orgánica de Protección de la Seguridad Ciudadana, como el Consejo Fiscal, en su informe al Anteproyecto de fecha 22 de enero de 2014, apreciaron que el precepto vulneraba el principio de culpabilidad por no contener ningún criterio de conexión individualizada de los posibles hechos típicos con las personas allí referidas. En la doctrina, Presno Linera (2014: 284) criticó que con la previsión del art. 29.3 del Anteproyecto de la LOPSC se atribuía responsabilidad «a los organizadores y promotores de reuniones y manifestaciones en lugares de tránsito público, aunque nada tengan que ver con los hechos cometidos en el transcurso de las mismas». Sin embargo, la LOPSC ya no contiene una previsión similar, pues el art. 30.3 determina quiénes son esos organizadores y promotores, siendo los tipos de los arts. 35.1 y 37.1 los que atribuyen la responsabilidad de esas concretas infracciones a esos sujetos.

54 Es, por ello, que no creo que tengan sentido las críticas como la efectuada por A. Alonso Rimo (2014: 4), que reprocha que la falta de comunicación previa de una reunión pacífica no debería autorizar «la sanción de quienes participen en la misma y por el mero hecho de hacerlo». Pues, como acabo de advertir, no se puede sancionar en virtud del precepto a cualquier participante, sino a los organizadores o promotores que han decidido incumplir las obligaciones que les impone la LODR. 
principio de culpabilidad, tal y como afirmó el CGPJ en su Informe al Anteproyecto de la LOPSC, y a los caracteres esenciales de nuestro sistema de responsabilidad administrativa sancionadora, en el que por regla general los responsables de las infracciones son los autores, salvo que una ley específica disponga otra cosa, siendo autores los que realizan la conducta típica ${ }^{55}$. Como explica Rebollo, son autores quienes «han podido decidir si se comete o no la infracción, cuándo y cómo. Los demás no serán autores aunque hayan propuesto, provocado, inducido o cooperado a la infracción, incluso con actos sin los cuales no se habría llevado a cabo" ${ }^{56}$. En el caso del art. 37.1 LOPSC, quienes deciden cometer la infracción son los organizadores o promotores de la reunión o manifestación, que acuerdan llevarlas a cabo y dirigirlas sin cumplir con los requisitos impuestos en la LODR. Destacadamente, sin presentar la preceptiva comunicación previa, sin adoptar las medidas de seguridad necesarias e impidiendo a la Administración prevenir perturbaciones del orden público. Los demás participantes pueden resultar fundamentales para la comisión de la infracción, pues sin su actuación quizá ni siquiera se desenvolviera la reunión o manifestación, pero no son responsables porque no han realizado la acción típica. Ellos, al no ser organizadores ni promotores ex art. 30.3 LOPSC, no son los llamados a cumplir los requisitos impuestos en la LODR. De hecho, puede que ni siquiera tengan constancia de la inexistencia de la comunicación previa y que participen en la manifestación convencidos de que es perfectamente legal ${ }^{57}$.

Puede concluirse que el art. 37.1 LOPSC es una norma sancionadora en blanco que tipifica como infracción el incumplimiento de una serie de requisitos establecidos en la LODR. Serán responsables, por tanto, los sujetos a los que la LODR exige cumplir dichos requisitos. Es decir, los organizadores o promotores de las reuniones. En este sentido, el art. 30.3 LOPSC solo coadyuva a la identificación de estos sujetos ${ }^{58}$. Es, por ello, que no creo que tengan mucho sentido

55 Rebollo Puig (2014: 2528-2529) lo explica y señala las diferencias que existen en el Derecho Penal, donde pueden ser responsables, porque así lo tipifica expresamente el CP, otros sujetos que participan en el delito sin ser sus autores (art. $27 \mathrm{CP}$ ), como los inductores, los cooperadores necesarios y los cómplices.

56 Rebollo Puig (2014: 2530).

57 M. B. López Portas (2016), «Una aproximación al derecho de reunión y manifestación a la luz de la llamada Ley Mordaza», Revista General de Derecho Constitucional, 23, págs. 1-24 (pág. 8).

58 No obstante, es cierto que el precepto puede ser criticable cuando identifica a los organizadores o promotores de la reunión o manifestación en caso de falta de comunicación previa con quienes las presiden o dirigen. A este respecto, véase Cuesta Bárcena (2021: 213-215). A pesar de ello, creo que debe interpretarse que, conforme a lo dispuesto en el artículo, en el caso concreto habrá que demostrar qué personas han promovido materialmente la reunión o manifestación y no conformarse con considerar responsables a aquellos que las dirigen o presiden, pues ello puede ser contrario a su derecho a la presunción de inocencia. Pero ni siquiera considero que se trate de una interpretación correctora conforme a la Constitución, sino de la única interpretación razonable que puede hacerse del precepto. 
las críticas vertidas contra la LOPSC por desplegar un efecto disuasorio (chilling effect) sobre aquellos que pretendan organizar una reunión o manifestación. Es la propia LODR la que les atribuye dicha responsabilidad. De hecho, también en el ámbito penal se procede de esta forma ${ }^{59}$.

Pero es que, además, la STC 172/2020 señala que, para ser castigado en virtud de este precepto en calidad de promotor u organizador, no basta «con tener objetivamente esta condición o que la misma se pueda deducir razonablemente de alguno de los hechos que recoge la norma u otros de similar naturaleza, ya que además se han de cumplir, como no puede ser de otro modo, las exigencias derivadas del principio de culpabilidad». Se requiere, por tanto, que los promotores u organizadores hayan actuado con dolo o culpa. No se trata, en consecuencia, de un supuesto de responsabilidad objetiva, de modo que sin una cierta negligencia que demuestre la existencia de un nexo causal entre la infracción cometida y la conducta poco diligente de los organizadores y promotores sería improcedente sancionarlos. De lo contrario, nos encontraríamos ante un supuesto de responsabilidad objetiva que prohíbe el sistema actual ${ }^{60}$. En este sentido, la sentencia aclara que la responsabilidad de organizadores y promotores se circunscribe al hecho de que la reunión o manifestación se haya celebrado incumpliendo los requisitos previstos en la LODR, sin incluir todo lo que suceda en esas reuniones o manifestaciones, ni todo lo que haga cada uno de los participantes en ellas ${ }^{61}$.

59 En el ámbito penal, el art. 494 CP considera autores del delito de reunión o manifestación ante las sedes del Congreso de los Diputados, del Senado o de una Asamblea Legislativa de Comunidad Autónoma, cuando estén reunidas, alterando su normal funcionamiento, a quienes las promueven, dirigen o presiden. Y el art. $514 \mathrm{CP}$ considera culpables del delito de reuniones o manifestaciones ilícitas del art. $513 \mathrm{CP}$ a sus promotores o directores, reputándose «directores o promotores de la reunión o manifestación los que las convoquen o presidan».

60 Así lo advirtió Rebollo Puig (2014: 2542) con relación al art. 23 c) LOPSC/92, que contenía una previsión similar a la del actual art. 30.3 LOPSC. Según el autor, este tipo de preceptos «no pueden admitirse ni ser entendidos como una enumeración de quienes, por ser lo que son $-\mathrm{y}$ no por lo que hagan (o dejen de hacer, estando obligados a hacerlo) - serán sancionados. Ninguno puede leerse como una atribución ex lege y definitiva de responsabilidad de quienes, aunque no hayan contribuido culpablemente a la infracción, deban ser sancionados. Para sancionar a los sujetos que esos preceptos citan será necesario que efectivamente en el caso concreto pueda achacárseles una conducta propia y culpable de contribución a la infracción. La inmensa mayoría de estas normas permite esa interpretación que es obligada para hacerlas conformes a la Constitución».

61 Se confirma lo ya advertido por Rebollo Puig (2019a: 154): «[...] esa responsabilidad de organizadores y promotores se contrae, no a todo lo que suceda en las manifestaciones o reuniones, no a todo lo que hagan cada uno de los asistentes o participantes, que pueden ser incontrolables y hasta saboteadores, sino solo y exclusivamente respecto a dos concretas infracciones, las de los arts. 35.1 y 37.1, en las que es la misma manifestación lo ilegal». A este respecto, véase también Huergo Lora (2019: 447-448). 
Como consecuencia de todo ello, la STC 172/2020 niega que los mencionados preceptos desalienten el ejercicio del derecho de reunión.

Por último, los recurrentes del Parlamento catalán aprecian una restricción injustificada del derecho de reunión en el art. 37.3 LOPSC, que tipifica como infracción leve: «El incumplimiento de las restricciones de circulación peatonal o itinerario con ocasión de un acto público, reunión o manifestación, cuando provoquen alteraciones menores en el normal desarrollo de los mismos». El Pleno del TC, por su parte, aprecia que este precepto busca compatibilizar el ejercicio del derecho de reunión con la efectividad de los derechos y libertades de terceros tipificando como infracción determinados supuestos de extralimitación en el goce del derecho y no su ejercicio regular. Sin embargo, reconoce que, dada la literalidad del precepto - conforme a la que puede entenderse que toda alteración menor en el desarrollo de una reunión es constitutiva de esta infracción-, puede suceder que las personas decidan «retraerse en el ejercicio normal de su derecho, al temer que por cualquier circunstancia inesperada terminasen incurriendo en los incumplimientos contemplados en la norma sancionadora». Para evitar este efecto desaliento en el disfrute del derecho - que convertiría al art. 37.3 LOPSC en inconstitucional- y en virtud del principio favor libertatis, la STC 172/2020 interpreta que, aunque el precepto alude a "alteraciones menores», en realidad se requiere que se trate de alteraciones «que sean verdaderamente relevantes, en el sentido de presentar una determinada entidad y gravedad ${ }^{6}{ }^{6}$. Vemos, de nuevo, la importancia que tiene la interpretación que se adopte a la hora de determinar si un determinado precepto es contrario a los mandatos constitucionales.

En definitiva, las SSTC 172/2020 y 13/2021 rechazan, por una parte, que las infracciones de la LOPSC limiten de forma injustificada el derecho de reunión y, por otra, que desincentiven su ejercicio. Pero, para esto último, lo cierto es que el TC no recurre expresamente a la doctrina del efecto desaliento. No la explica y casi ni la menciona. Aunque obviamente está latente en su pronunciamiento porque, en realidad, esta doctrina no es más que la aplicación de la garantía de tipicidad y del principio de proporcionalidad en los casos concretos de infracciones que tipifican conductas limítrofes con el ejercicio de un derecho fundamental. Quien sí que ha esgrimido esta doctrina para poner de manifiesto su disconfor-

62 Precisamente esta interpretación es uno de los aspectos de la STC 172/2020 más criticados en el voto particular. La magistrada discrepante considera que el Pleno del TC ha modificado el contenido del precepto por vía interpretativa hasta el punto de que «las alteraciones menores han pasado a ser alteraciones relevantes por su entidad o gravedad». A su parecer, «estirar el significado de una palabra para hacerle decir lo contrario es reconocer que la expresión contenida en el precepto no respeta los límites que dice aplicar la sentencia». Para evitar este tipo de críticas, creo que la sentencia debería haber insistido en el hecho de que se requiere una alteración de cierta envergadura y gravedad, pero aun así «menor», pues, de lo contrario, no se cometería esta infracción leve, sino la grave del art. 36.8 LOPSC ( La perturbación del desarrollo de una reunión o manifestación lícita, cuando no constituya infracción penal»). 
midad con el voto de la mayoría ha sido la magistrada discrepante que en ambos casos lamenta que el Pleno haya "convalidado" el efecto desaliento que en su opinión generan algunas de las infracciones de la LOPSC (en concreto, las recogidas en sus arts. 36.2, 37.1 y 37.3 ).

\section{LA ÚNICA DECLARACIÓN DE INCONSTITUCIONALIDAD: EL INCISO «NO AUTORIZADO»DEL ART. 36.23 LOPSC}

De todos los preceptos de la LOPSC que fueron impugnados las sentencias solo han declarado que es inconstitucional la expresión «no autorizado» que está en el tipo del art. 36.23 LOPSC. La STC 172/2020 ha dado la razón a los recurrentes y ha suprimido ese inciso por resultar contrario a la interdicción de censura previa que establece el art. 20.2 CE, ya que podía interpretarse que establece la necesidad de obtener una autorización administrativa previa para la actividad consistente en usar imágenes o datos de las autoridades o miembros de las Fuerzas y Cuerpos de Seguridad ${ }^{63}$.

En este caso, parece que el TC ha considerado más oportuno declarar la inconstitucionalidad de estas dos palabras del precepto que hacer una interpretación que resulte conforme a la Constitución. Me parece bien y no creo que sea reprochable porque realmente el inciso suprimido no aportaba ningún valor al precepto $^{64}$. No obstante, habría sido igualmente viable que la sentencia hubiera interpretado este precepto como lo hizo en su momento Rebollo, es decir, considerando que la expresión «no autorizado» no se refiere a la previa obtención de una autorización administrativa en sentido estricto, sino a «no autorizado por el ordenamiento» ${ }^{65}$. Así entendido, el precepto sancionaría el uso "no lícito» de imágenes o datos personales o profesionales de autoridades o miembros de las Fuerzas y Cuerpos de Seguridad que pueda poner en peligro la seguridad personal o familiar de los agentes, de las instalaciones protegidas o en riesgo el éxito de una operación, con respeto al derecho fundamental a la información. Lo que sería perfectamente constitucional.

\section{SIN NOVEDADES SOBRE LA FRONTERA ENTRE EL DERECHO PENAL Y EL DERECHO ADMINISTRATIVO SANCIONADOR}

Muchas de las críticas que se vertieron contra la LOPSC fueron por haber hurtado la garantía del juez penal, o sea, por transformar delitos o faltas del CP

\footnotetext{
63 El TC se ha hecho, así, eco de la demanda de la doctrina constitucional. Véanse, entre otros, Bilbao Ubillos (2015: 248-249) y Presno Linera (2016: 55).

64 Véase, sobre esto, Martín Fernández (2019: 574).

65 Rebollo Puig (2019a: 166).
} 
que correspondía castigar a los jueces en infracciones sancionadas por la Administración. Esta pérdida de garantías procesales no se paliaba por el hecho de que las resoluciones administrativas sancionadoras pudieran ser controladas a posteriori por la jurisdicción contencioso-administrativa. Con ello, según se denunció en su momento, no solo se perdía la garantía más esencial que comporta la actuación de un órgano judicial, que es imparcial y objetivo, sino que arrastraba otras consecuencias secundarias, pero muy relevantes sobre la oralidad, la ejecutividad de los castigos, las pruebas posibles, la asistencia letrada gratuita, etc. De hecho, las críticas más serias que se hicieron en su momento a la LOPSC y a la Ley Orgánica 1/2015 de reforma del Código Penal, que fue la otra pieza clave de la reforma, insistieron en todo esto ${ }^{66}$.

Paralelamente, la doctrina se ha venido esforzando por encontrar una posible frontera entre el derecho penal y el derecho administrativo sancionador y establecer los posibles límites que deberían de tenerse en cuenta a la hora de decidir qué ilícitos deberían de ser castigados por los jueces y ser tipificados como delitos y cuáles otros habrían de convertirse en infracciones y ser sancionadas por las Administraciones públicas ${ }^{67}$.

Pocas ocasiones mejores se presentarán para que el TC pueda arrojar alguna luz sobre este capital asunto que el que ofrecían la LOPSC y la Ley Orgánica 1/2015 de reforma del Código Penal que, como se sabe, suprimió radicalmente el libro de las faltas. Además, el contexto en que esto se producía era especialmente propicio para haberse adentrado en ello. Es verdad que el debate es mucho más amplio y que podría plantearse igualmente ante las infracciones contra la competencia, las de seguridad laboral, las de extranjería y otras muchas. Pero las infracciones de seguridad ciudadana son, si así cabe decirlo, singularmente sensibles. Al menos, algunas de ellas, aquellas en que la conducta tipificada consiste en un exceso sobre lo que permiten los derechos fundamentales. Estando en juego derechos fundamentales y siendo a veces tan lábil y sutil la línea que separa el ejercicio lícito del ilícito de esos derechos fundamentales, solo el juez puede ofrecer una garantía real e inmediata, no una autoridad administrativa, aunque quizá mucho después pueda haber un eventual control judicial. Máxime cuando se trata de derechos fundamentales como los de información, reunión y manifestación que con frecuencia tienen implicaciones políticas y hasta partidistas directas. Dicho ejemplificativamente, no ofrece serias garantías que el delegado del Gobierno del partido político X sea quien castigue los excesos de las manifestaciones promovidas por el partido político Y, ni que al poco tiempo se cambien las tornas, y tampoco cabe alber-

66 Alarcón Sotomayor (2019: 337) y Bilbao Ubillos (2015: 241).

67 Por todos, L. Alarcón Sotomayor (2014), «Los confines de las sanciones: en busca de la frontera entre Derecho Penal y Derecho Administrativo sancionador», Revista de Administración Pública, 195, págs. 135-167. 
gar muchas esperanzas de objetividad cuando coincidan el partido político del titular del órgano sancionador y del promotor de la manifestación ${ }^{68}$.

Aclaremos que reconocer, como es obvio, que el mantenimiento de la seguridad ciudadana es una labor esencial de la Administración, no de los jueces, no significa de ningún modo que la punición de conductas contrarias a la seguridad ciudadana haya de ser también competencia de aquella y no de estos. Muy al contrario, el modelo ideal de Estado de derecho confía a la Administración toda la amplia labor de prevención en pro de la seguridad ciudadana, pero atribuye a los jueces el castigo de las conductas que hayan perturbado ese valor. Así que aquella función preventiva esencial de la Administración no justifica por sí sola la conversión de los delitos y faltas correspondientes en infracciones administrativas ni que la represión de las nuevas conductas tipificadas por lesionar tal bien jurídico se encomiende a la Administración. Al contrario, confiar la punición de esas conductas a la Administración puede resultar especialmente inadecuado y hasta peligroso.

Por todo ello, sobre todo por tratarse de la represión de conductas tan conectadas con derechos fundamentales y por las garantías que se pierden, como la del juez penal, la LOPSC ofrecía una oportunidad excelente para que el TC hubiera aportado criterios orientativos sobre la licitud de operaciones despenalizadoras tan delicadas como la que realizó el legislador en 2015. Pero, al parecer, los recursos no apuntaron nada en este sentido y, consecuentemente, las sentencias omiten cualquier consideración a este respecto. Así que lo que podría haber sido lo más interesante y lo que, en el fondo, reclamaban las críticas más sensatas contra la LOPSC queda sin ninguna respuesta ${ }^{69}$.

\section{CONCLUSIONES}

Las SSTC 172/2020, de 19 de noviembre, y 13/2021, de 28 de enero, han declarado la constitucionalidad de la LOPSC y, en concreto, la de su régimen san-

68 A este respecto, véase M. Rebollo Puig (2020), «Derecho Administrativo sancionador y Derecho Penal: conciliación y conflicto», en F. A. Castillo Blanco (dir.), Defensa del patrimonio público y represión de conductas irregulares (págs. 19-71), Madrid: Iustel (pág. 50). Sostiene el autor que «hay sectores sensibles en los que la garantía del juez, con su independencia e imparcialidad reforzada, se hace especialmente necesaria». Entre ellos se refiere a «los ilícitos cometidos con ocasión de manifestaciones o en cualesquiera disturbios con motivaciones políticas». Y reflexiona: «¿Conviene que se dé la potestad punitiva a la Administración o a los jueces?, ¿conviene que quede en manos de una autoridad administrativa, acaso del mismo partido político de los perturbadores o del partido rival o es mejor que corresponda a los jueces? La respuesta me parece obvia. Y ya no sólo porque es objetivamente mejor, sino porque en muchos casos la sanción administrativa (o la inexistencia de sanción administrativa), aunque no lo fuese, podría ser vista como parcial por los ciudadanos, como un arma en la lucha partidista».

69 Alarcón Sotomayor (2019: 302-303 y 337). 
cionador. El TC ha desestimado todos los motivos de impugnación esgrimidos por los recurrentes, salvo el relativo al inciso «no autorizado» del tipo previsto en el art. 36.23 LOPSC, que ha declarado inconstitucional. Algo insignificante para tratarse de una ley que parecía que iba a acabar con nuestro sistema democrático y a instaurar un régimen represivo en el que los ciudadanos no iban a poder ejercer sus derechos y libertades. No parece que haya sido así. De hecho, se confirma que algunas críticas fueron prematuras y muchas otras muy poco fundamentadas y exageradas. Otra vez se han tenido que asumir como jurídicas unas críticas que, en verdad, eran eminentemente políticas e ideológicas.

Además de esta conclusión principal, del estudio precedente pueden extraerse algunas otras más específicas:

Según el TC, la seguridad ciudadana forma parte del concepto de orden público y, en concreto, de la seguridad pública. Constituye «el estado en el que el conjunto de la ciudadanía goza de una situación de tranquilidad y estabilidad en la convivencia que le permite el libre y pacífico ejercicio de los derechos y libertades que la Constitución y la Ley les reconocen».

- A juicio del TC, no solo es digno de protección el normal funcionamiento de las Cámaras legislativas, sino también su mera simbología como edificios que albergan la voluntad popular.

- La LOPSC no puede considerar infracción el uso «no autorizado» de imágenes o datos de miembros de las Fuerzas y Cuerpos de Seguridad, pues la alusión a una autorización es contraria a la interdicción de censura previa del art. 20.2 CE.

- El art. 37.1 LOPSC, al responsabilizar de la conducta que tipifica (la celebración de reuniones incumpliendo los requisitos de la LODR) a los organizadores o promotores de reuniones o manifestaciones, lejos de ser contrario a los principios de culpabilidad y personalidad de las sanciones, ejerce una función reductora de la responsabilidad, delimitando quiénes pueden ser considerados responsables de entre aquellos que intervengan culpablemente en la infracción.

Y algunas generales:

- La exigencia constitucional de lex certa no se opone a la utilización de conceptos jurídicos indeterminados en la definición de la conducta infractora, siempre que su concreción sea razonablemente previsible en virtud de criterios lógicos, técnicos o de experiencia. Es algo que viene sosteniendo desde antiguo el TC. Con las sentencias examinadas se pone de manifiesto que quizá no habría que alardear tanto del carácter «absoluto» de la garantía de tipicidad.

- La interpretación de un tipo infractor no debe realizarse de forma aislada. Debe de ser sistemática, teniéndose en cuenta a qué ley pertenece, cuál es su finalidad y con qué otros preceptos puede guardar relación. Solo así podrá 
comprenderse verdaderamente cuál es la conducta típica y, a raíz de ello, deducir si la norma sancionadora respeta o no todas las exigencias constitucionales.

- Una norma sancionadora en blanco que no establezca expresamente la norma o normas a las que se remite no es, solo por eso, contraria al principio de legalidad administrativa sancionadora. Para ello, se requiere que no pueda conocerse cuál es la norma remitida, lo que no suele suceder cuando se trata de un sector de actividad muy específico.

- La labor de la doctrina y de la jurisprudencia es esencial, pues con sus aportaciones se pueden interpretar las leyes y sus preceptos para que sean acordes a la Constitución. Ello no significa que, mediante la interpretación propuesta por la doctrina y la jurisprudencia se puedan tergiversar los conceptos y hacer decir a las leyes aquello que no dicen, sino al contrario, aquellas pueden clarificarse y determinarse de modo que sean perfectamente compatibles con nuestra Norma Suprema. 